University of Louisville

ThinkIR: The University of Louisville's Institutional Repository

Electronic Theses and Dissertations

$5-2012$

\title{
Approaches in the treatment of Parkinson's disease : a focus on stem cell-based therapies.
}

Tareq Al-maqtari 1979-

University of Louisville

Follow this and additional works at: https://ir.library.louisville.edu/etd

Part of the Pharmacy and Pharmaceutical Sciences Commons

\section{Recommended Citation}

Al-maqtari, Tareq 1979-, "Approaches in the treatment of Parkinson's disease : a focus on stem cell-based therapies." (2012). Electronic Theses and Dissertations. Paper 34.

https://doi.org/10.18297/etd/34

This Master's Thesis is brought to you for free and open access by ThinkIR: The University of Louisville's Institutional Repository. It has been accepted for inclusion in Electronic Theses and Dissertations by an authorized administrator of ThinkIR: The University of Louisville's Institutional Repository. This title appears here courtesy of the author, who has retained all other copyrights. For more information, please contact thinkir@louisville.edu. 


\title{
APPROACHES IN THE TREATMENT OF PARKINSON'S DISEASE: A FOCUS ON STEM CELL-BASED THERAPIES
}

\author{
By
}

\author{
Tareq Al-maqtari \\ B.S., Aleppo University, Syria, 2003

\begin{abstract}
A Thesis Submitted to the Faculty of the
School of Medicine of the University of Louisville in

Partial Fulfillment of the Requirements for the Degree of
\end{abstract}

Master of Science

Department of Pharmacology \& Toxicology

University of Louisville

Louisville, $\mathrm{KY}$

May 2012 


\section{APPROACHES IN THE TREATMENT OF PARKINSON'S DISEASE: A FOCUS ON}

STEM CELL-BASED THERAPIES

\section{By}

Tareq Al-maqtari

B.S., Aleppo University, Syria, 2003

A Thesis Approved on

March 1, 2012

By the following Thesis Committee:

Uma Sankar, Ph.D.

J. Christopher States, Ph.D.

Theo Hagg, M.D., Ph.D. 


\section{DEDICATION}

This Thesis is dedicated to my beloved wife (Hanaan Al-maqtari) and my lovely kids (Bara'ah, Sondos, and Mohammed) for their unlimited love and support. 


\section{ACKNOWLEDGEMENTS}

It is my pleasure to express my gratitude to my mentor, Dr. Uma Sankar, for her continuous support and guidance. Her motivation and insightful critiques were key to finishing this work. I would also like to thank my graduate committee members, Drs. Theo Hagg and J. Christopher States, for their insightful comments and valuable suggestions. I also appreciate the moral support and guidance of my Louisville parents, Dr. Peter Rowell and Sharon Carpenter. Lastly, I would love to thank my wife, Hanaan Al-Maqtari, and my three kids for their unlimited love and support. 


\section{ABSTRACT \\ APPROACHES IN THE TREATMENT OF PARKINSON'S DISEASE: A FOCUS ON STEM CELL-BASED THERAPIES \\ Tareq Al-maqtari \\ March 1, 2012}

Parkinson's disease (PD) is a hypokinetic movement disorder resulting from the progressive neurodegeneration of the dopaminergic nigrostriatal system in the brain and the resulting imbalance between dopamine and acetylcholine in the basal ganglia motor circuitry. Although drug-based therapy approaches have shown dramatic symptomatic improvement in patients, they do not halt the progressive nature of the disease and their long-term use is associated with distressing adverse side effects. Consequently, several studies have aimed at discovering effective non-pharmacological strategies to reduce or to eliminate the need for drugs and possibly to halt or to reverse the neurodegenerative process in PD. Surgical deep brain stimulation, neurotrophic factor delivery, gene therapy and cell replacement therapy are potential candidates. Here, we review the latest advancements in the aforementioned therapeutic strategies paying special attention to regenerative stem cell- (SC)-based approaches in combating PD. Although intracerebrally transplanted SC-derived cells can replace degenerated neurons in PD and simultaneously secrete neurotrophic factors that can partly protect the viable ones, potential tumorigenicity and low survivability of these cells hinder the advancement of this novel therapeutic approach. Hence, more investigations are needed to resolve the associated safety and efficacy concerns in order to make SC-based therapy a feasible therapy for PD patients. 


\section{TABLE OF CONTENTS}

PAGE

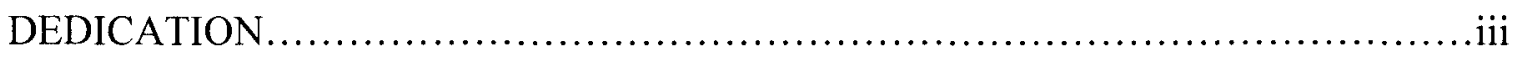

AKNOWLEDGEMENTS ........................................................

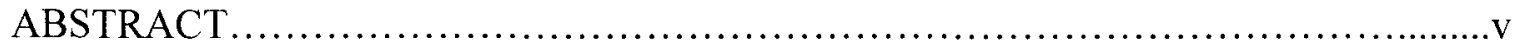

CHAPTER I. INTRODUCTION ..............................................

CHAPTER II. ALTERNATIVE THERAPEUTIC APPROACHES IN PD ...............11

CHAPTER III. CELL REPLACEMENT THERAPY FOR PD ......................22

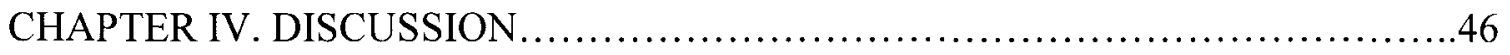

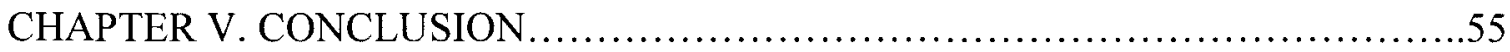

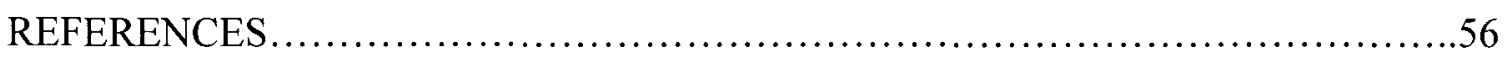

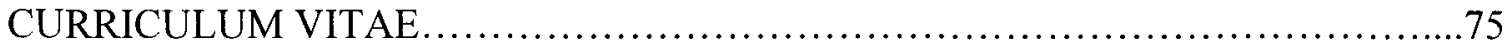




\section{CHAPTER I \\ INTRODUCTION}

\section{Parkinson's Disease}

Parkinson's disease (PD) is a progressive degenerative disorder of the central nervous system that primarily affects the elderly. It is named after the English doctor, James Parkinson, who first described the disease in 1817. PD affects around 18 per 100,000 person-years and has a higher prevalence in males (Corti et al., 2011). The degenerative symptoms of PD arise primarily from the progressive loss of dopaminergic neurons in the substantia nigra pars compacta (SNpc) of the midbrain (see figure 1) and result in motor system abnormalities such as bradykinesia, tremors, muscular rigidity and postural instability (Halliday and McCann, 2010).

PD-related symptoms progress in a time-dependent manner such that the presymptomatic stages are associated with smell and autonomic dysfunctions, the symptomatic stages with motor abnormalities, and the final stages with dementia in many cases. The slow progression of the disease results from neurodegeneration afflicting the olfactory bulb and the medulla oblongata in pre-symptomatic stages 1 and 2, the SNpc in stages 3 and 4, and the telencephalic cortex in stages 5 and 6 (Braak et al., 2002). The fact that PD patients also experience non-motor psychiatric, cognitive and autonomic symptoms indicates that non-dopaminergic neurons also become affected in the course of the disease (Chaudhuri et al., 2006). 


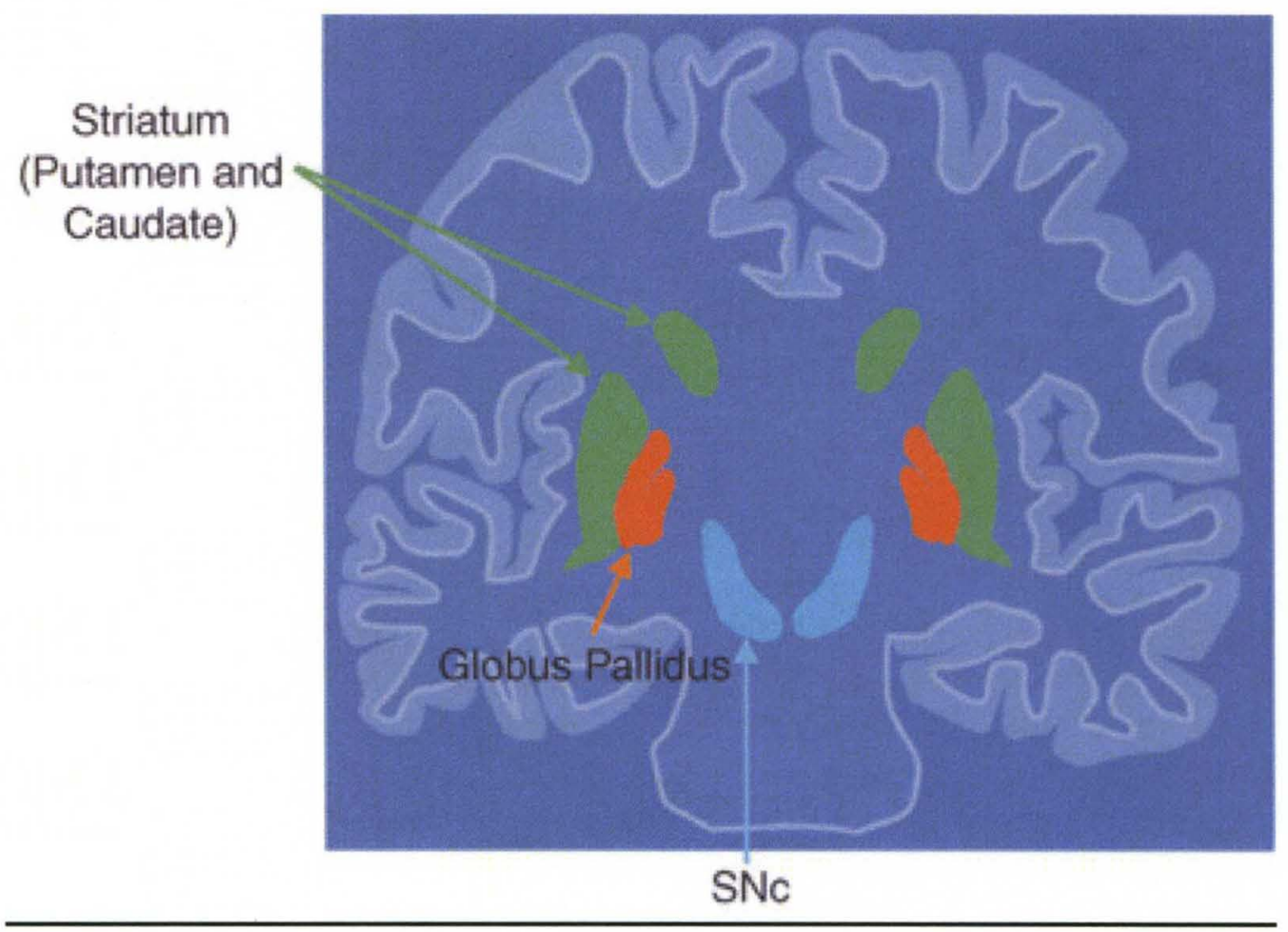

Figure 1. Dopaminergic neurons of the substantia nigra compacta ( $\mathrm{SNc}$ ), which extend to the striatum., degenerate in Parkinson's disease. (Source of the picture: Longo DL, Fauci AS, Kasper DL, Hauser SL, Jameson JL, Loscalzo J: Harrison's Principals of Internal Medicine, $18^{\text {th }}$ Edition, www.accessmedicine.com)

\section{Protein Aggregation and PD pathophysiology}

Although the exact cause of PD remains largely unknown; inflammation, oxidative stress, mitochondrial damage, dysfunction of the ubiquitin proteosome degradation system, and altered activity of certain kinases, all appear to promote the formation of Lewy bodies, intracellular proteinaceous aggregates observed in PD-affected dopaminergic neurons, eventually resulting in neuronal cell death (McNaught et al., 2003; Schulz, 2008). The components of Lewy bodies include alpha-synuclein (SNCA) the major fibrillary component of these bodies, neurofilament proteins and ubiquitin (Corti et al., 2011). SNCA is abundantly expressed in the brain especially at presynaptic 
nerve terminals where it may modulate dopaminergic transmission ( $\mathrm{Li}$ et al., 2004). Mutations in $S N C A$ increase the tendency of the corresponding protein to aggregate into Lewy bodies, resulting in neuronal cell death (Goedert et al., 1998). Whereas the exact mechanistic relationship between Lewy bodies and cell death remains obscure, there is some evidence that SNCA oligomers, not the fibrillary form, are responsible for neuronal cell death (Goldberg and Lansbury, 2000), suggesting a possible detoxification role for the Lewy bodies. These conclusions are supported by observations that Lewy bodies exist in the surviving neurons of PD patients as well as in the neurons of healthy individuals (Parkkinen et al., 2005). Further, some studies postulate that dopamine plays a role in stabilizing SNCA oligomers, promoting the selective degeneration of dopaminergic neurons (Lansbury et al., 2001). Although the exact role of SNCA in PD remains largely unknown, the general consensus is that its accumulation disrupts multiple cellular events and induces distinctive neurodegeneration (Litvan et al., 2007b).

\section{Genetic causes of PD}

Most cases of PD are spontaneous or idiopathic in nature with a small percentage resulting from specific genetic mutations (de Lau and Breteler, 2006). In general, familial PD patients exhibits the same clinical picture as sporadic PD patients except for an earlier onset in many but not all inherited cases (Gasser, 2007). Genes coding for SNCA $(S N C A)$, leucine rich repeat kinase 2 ( $L R R K 2)$ and ubiquitin carboxyl-terminal hydrolase L1 (UCH-LI) are involved in autosomal dominant forms, whereas genes coding for parkin $(P R K N)$, PTEN-induced putative kinase 1 (PINKI), ATPase type $13 \mathrm{~A} 2$ (ATP13A2), and the Parkinson's disease associated protein DJ-1 (PRKN7) are involved in autosomal recessive forms of PD (Schulz, 2008). The identification of these genes has 
shed light on the molecular pathophysiology of the disease, but the precise role of these genes in healthy and PD patients remains largely unknown (Hatano et al., 2009). Most of these genes appear to interact with one another and play roles in mitochondrial function, oxidative stress and/or protein ubiquitination.

Identification of point mutations and genomic multiplications in SNCA, the first PD gene to be mapped, led to the discovery that the encoded protein is the main component of Lewy bodies, the pathological hallmark in familial and sporadic PD (Corti et al., 2011). SNCA is a small protein $(140 \mathrm{KDa})$ whose overexpression, through duplication and triplication of the encoding gene, is associated with neuronal toxicity in humans and in animal models, indicating that gain-of-function mutations also contribute to the pathogenesis of PD (Martin et al., 2011). Recent studies demonstrate that SNCA promotes assembly of soluble N-ethylmaleimide sensitive factor attachment protein receptor complexes (that are required for fusion of vesicles to the presynaptic neuronal membrane), suggesting a potential role of SNCA in dopaminergic transmission (Martin et al., 2011).

$L R R K 2$ is the other gene most commonly associated with late-onset, autosomal dominant form of familial PD (Gasser, 2007). Like SCNA, the exact function of LRRK2 in the brain remains obscure. However, LRRK2 kinase activity is associated with cellular toxicity and neuronal cell death and the gain-of-function point mutations of LRRK2, observed in familial and sporadic PD, result in enhanced kinase activity (Cookson et al., 2007). Mutations in LRRK2 are not necessarily associated with the formation of Lewy bodies (Funayama et al., 2002). Nonetheless, they constitute the major genetic mutations associated with familial PD. 
Loss-of-function mutations in $P R K N$ were first discovered among the Japanese to cause autosomal recessive, early-onset familial PD with no Lewy body accumulation (Hatano et al., 2009). PRKN is a protein localized primarily in the cytoplasm that tags proteins for proteosomal degradation. As an E3 ubiquitin ligase in the ubiquitin-protesome degradation system, mutations in PRKN are postulated to impair its ability to interact with E2 ubiquitinating enzymes, leading to the buildup of nonubiquitinated substrates that leads eventually to neuronal cell death (Dawson and Dawson, 2010; Shimura et al., 2000). Like $P R K N, P I N K 1$ and $D J-1$ are also responsible for autosomal recessive forms of PD. These three genes are involved in pathways that regulate mitochondrial morphology and function, corroborating the role of mitochondrial damage in the etiology of PD (Corti et al., 2011). It has been proposed that PINK1 is a protein located in the mitochondria that interacts with DJ-1 to modulate the activity of PRKN in protein ubiquitination (Xiong et al., 2009). Hence, loss-of-function mutations in PINKI hinder the role of the encoded protein in a mitochondrial quality-control pathway, resulting in neuronal dysfunction and death (Martin et al., 2011). On the other hand, DJ-1 is thought to maintain the integrity and functionality of mitochndria against oxidative stress (Thomas et al., 2011). DJ-1 undergoes a modification at a conserved cystein residue before relocating into the mitochondria where it exerts its protective effect (Canet-Aviles et al., 2004). However, further investigations are needed to confirm the precise role of PINK1 and DJ-1 in patients and healthy individuals.

$U C H-L I$ is expressed abundantly in the brain and appears to act as a deubiquitinating enzyme and has been observed as a component of Lewy bodies in sporadic PD (Larsen et al., 1998; Lowe et al., 1990). There is very little known about the physiological and 
pathological roles of $A T P 13 A 2$ although it appears to play a role in protein degradation via lysosomal pathways (Hatano et al., 2009). Other PD-related genes include Htr serine peptidase 2 (HTRA2/OMI) that possibly plays a role in protecting neurons from oxidative stress in a common pathway that involves PINK1, PRKN (Tain et al., 2009), phospholipase A2 group VI (PLA2G6) and F-box protein 7 (FBXO7) (Lesage and Brice, 2009). Taken together, whereas substantial progress has been made in the identification of genes related to PD, relatively little is known regarding the function of these genes in the etiology of the disease. Therefore, further investigations are needed to help elucidate their role to pave the road for targeted therapies in the treatment of PD.

\section{$\underline{\text { Dopamine and PD }}$}

Dopamine and acetylcholine are central components of the movement-regulating neuronal circuits in the basal ganglia. Onset of familial and sporadic PD is characterized by the death of dopaminergic neurons of the SNpc, resulting in diminished dopamine release into the striatum which in turn leads to the classical motor disturbances observed in PD. Therefore, restoring dopamine/acetylcholine balance is the primary goal of pharmacotherapy aimed at mitigating symptoms associated with PD.

\section{Pharmacological approaches in the treatment of PD}

Levo-dopa, the precursor of dopamine, is a highly effective drug in the treatment of PD, especially when used in the early stages. It crosses the blood-brain barrier, which separates systemic circulation from the brain extracellular fluid, and restores dopamine levels in the striatum of PD patients. However, levo-dopa is metabolized by the peripheral nervous system resulting in distressing side effects such as dyskinesia, shorter 
duration of drug-induced benefit (wearing off), and on-off pulsatile response fluctuations associated with long-term levo-dopa. Peripheral decarboxylase inhibitors (carbidopa, benserazide) are usually administered with levo-dopa to decrease its peripheral metabolism and enhance its activity in the central nervous system (Olanow et al., 2006). Nonetheless, levo-dopa does not address the cause of PD and does not improve the nonmotor autonomic, affective and cognitive symptoms accompanying the disease.

Other anti-PD drugs include dopaminergic receptor agonists, inhibitors of dopamine degradation, and anticholinergic agents. Dopaminergic receptor agonists act by direct stimulation of the dopaminergic receptors in the brain and include bromocriptine, pergolide, pramipexole and ropinirole. If used before L-dopa, they delay the onset of drug therapy-induced dyskinesia but at the expense of poorer management of motor symptoms (Clarke and Guttman, 2002). Inhibitors of dopamine metabolism prolong the efficacy of levo-dopa and include monoamine oxidase $\mathrm{B}$ inhibitors (selegiline, rasagiline) and catechol-o-methyltransferase inhibitors (tolcapone, entacapone). Monoamine oxidase B inhibitors undergo extensive first-pass metabolism, resulting in production of active amphetamine metabolites and low bioavailability, and are associated with insomnia, psychosis and cardiac arrhythmias (Poston and Waters, 2007). Catechol-omethyltransferase inhibitors can be added to the conventional levo-dopa/carbidopa combination to provide better symptomatic control in PD patients (Sethi et al., 2009). Anticholinergic agents are less effective and act by blocking the muscarinic receptors to restore the functional balance between dopamine and acetylcholine in the basal ganglia (Mestre and Ferreira, 2010). They may be used alone or in combination with levo-dopa to improve the motor functions in PD patients. However, They may induce 
neuropsychiatric, cognitive and other typical anticholinergic side effects (dry mouth, blurred vision, urinary retention, and cardiotoxicity) (Katzenschlager et al., 2003).

All the aforementioned anti-PD drugs are accompanied with adverse side effects and do not halt or reverse disease progression (Toulouse and Sullivan, 2008). More importantly, the effectiveness of these drugs depends greatly on the functionality of the remaining dopaminergic neurons to synthesize and secrete dopamine which decreases as the degeneration worsens. In addition, a recent study showed that the total cost of PD were approximately 8640 Euros per patient over a 6-month period. Anti-PD drugs were the major component of costs paid by the health insurance companies (39.6\%), constituting a quarter of PD direct costs (Winter et al., 2010). Another report estimated the annual cost of prescribed drugs post-treatment initiation at $\$ 3854$. However, $~ 67 \%$ of patients do not adhere well to drug therapy due to the multiple dosing and regimen complexity of antiPD drugs leading to disease worsening and $\sim \$ 3451$ annual increase in all-cause PD associated costs (Davis et al., 2010). Hence, there is an urgent need for new and improved therapies that can replace or reduce the need for anti-PD medications in the treatment of PD.

As current pharmacotherapy does not prevent the progression of $\mathrm{PD}$, it is imperative that new treatment strategies be developed that can replenish lost dopaminergic neurons and/or prevent the loss of these neurons in affected individuals. Development of drugs that enhance neurogenesis and/or help mobilize newly-formed neurons to the affected brain areas is an interesting approach for the treatment of PD that needs to be further investigated. For instance, serotonin stimulates brain-derived neurotrophic factor (a secreted protein that enhances neurons maturation and survival) expression and the 
administration of selective serotonin reuptake inhibitors enhances the activity of brainderived neurotrophic factor and alleviates symptoms of Huntington's disease in a mouse model (Duan et al., 2008). Similarly, dopaminergic receptor D2 and adrenergic receptor alfa-2 agonists and antagonists, respectively, have been shown to promote neurogenesis in murine animals (Borta and Hoglinger, 2007; Rizk et al., 2006). Both the excitatory neurotransmitter glutamate and the inhibitory neurotransmitter gamma-aminobutyric acid (GABA) play roles in neurogeneration and, hence, may be potential targets for pharmacological intervention to treat neurodegenerative diseases (Hagg, 2009). Further, nicotine is thought to enhance subventricular zone neurogenesis through the activation of cholinergic nicotinic receptors, resulting in downstream increase of fibroblast growth factor 2 (FGF-2). Kainic acid, however, appears to enhance FGF-2-mediated neurogenesis through a cannabinoid receptor-1 dependent manner (Aguado et al., 2007). Advantages of these pharmacological approaches include: (i) availability of many candidate drugs with established safety profiles, (ii) ease of administration, and (iii) the feasibility of withdrawing drugs in case adverse side effects and/or complications occur. However, several impediments still exist including: (i) possible failure of these drugs due to severe degeneration in their respective sites of action and/or due to down-regulation of their receptors, (ii) potential side effects and/or toxicities, and (iii) lack of knowledge regarding the precise site of action, the potentially-affected tissues and exact mechanism of action of the drugs (Hagg, 2009). Obviously, generating small molecules that can directly stimulate receptors of neurotrophic factors is likely to prove valuable.

Gene therapy, neurotrophic factor treatment and cell replacement therapy are all currently being developed as potential options in combating this degenerative disorder. A 
combinatorial strategy may be the most effective approach for replacing the dopaminergic neurons that are lost during the course of the disease and protecting the remaining neurons. In the following chapters, we discuss the current status of nonpharmacological approaches with a special focus on stem cell (SC) based cell replacement therapy in the treatment of PD. 


\section{CHAPTER II}

\section{ALTERNATIVE THERAPEUTIC APPROACHES IN PD}

The failure of pharmacological agents to halt the progressive neurodegeneration in PD has resulted in the development of alternative therapeutic approaches including brain stimulation, neurotrophic factor-based therapies, gene therapy, fetal midbrain graft transplantation, and SC-based therapy.

\section{Deep brain stimulation}

Deep brain stimulation is used in the advanced stages of PD and involves the surgical implantation of a brain pacemaker usually in the subthalamic nucleus or the globus pallidus pars interna. The pacemaker sends high frequency electrical impulses resulting in the mitigation of the symptoms of PD, which in turn helps in reducing the dose of antiPD drugs. Deep brain stimulation is implemented only in advanced cases when drugtreatment is no longer effective or is accompanied by distressing side effects. Since its approval by the food and drug administration in 2002, deep brain stimulation has improved motor symptoms (bradykinesia, rigidity, tremors and dyskinesia) in many PD patients for up to 5 years and appears to induce better results in L-dopa-responsive patients with intact cognitive abilities (Bronstein et al., 2011). However, since deep brain stimulation requires a major surgery in the brain, and does not address or reverse the cause of neurodegeneration, it is viewed as a less attractive approach in the treatment of PD. 


\section{Neurotrophic factor-based therapy}

Neurotrophic factors are secreted proteins that play a key role in the induction, specification, maturation, survival and protection of neurons (Sullivan and Toulouse, 2011). Therefore, lack of neurotrophic factors has been hypothesized to contribute to the pathophysiology of PD (Connor and Dragunow, 1998). Neurotrophic factors that act on dopaminergic neurons include: members of the classic neurotrophin family such as brainderived neurotrophic factor, glial cell line-derived neurotrophic factor (GDNF) family such as GDNF and neurturin, and novel neurotrophic factors such as conserved dopamine neurotrophic factor and mesencephalic astrocyte-derived neurotrophic factor. Of all the identified neurotrophic factors, GDNF and neurturin have shown the most encouraging results as therapeutic targets for degenerative disorders. Whereas the advantage of delivering a combination of neurotrophic factors using single gene-delivery approach is enticing, albeit controversial (Sun et al., 2005; Zurn et al., 1996), delivering these factors into the brains of patients is problematic. This is because the neurotrophic factors cannot pass the blood brain barrier and undergo rapid metabolism, raising the need for longlasting local delivery system. In addition to direct intracerebral infusion, transplantation of neurotrophic factor-expressing cells and in vivo gene therapy have all been implemented to deliver sufficient quantities of neurotrophic factors to the brain (Rangasamy et al., 2010).

\section{Glial cell line-derived neurotrophic factor (GDNF)}

GDNF is a member of the GDNF family of neurotrophic factors that also include neurturin, artemin and persephin. The GDNF family of proteins bind to 
glycosylphosphatidylinositol (GPI)-linked receptors called GDNF family receptors alpha 1,2,3 and (GFR $\alpha 1,2,3$ and-4), and activate a transmembranous tyrosine kinase, rearranged during transfection (RET), to induce downstream signaling that includes mitogen activated protein kinase (MAPK) and phospholipase $\mathrm{C} \gamma$ pathways (Sariola and Saarma, 2003). GDNF has been isolated from glial cells and was confirmed to exert neuroprotective effect on cultured dopaminergic neurons (Lin et al., 1993). Furthermore, GDNF has been shown to induce tyrosine hydroxylase, the rate-limiting enzyme in dopamine synthesis, in fetal human and rat cerebral cortical cultures (Theofilopoulos et al., 2001).

In vivo studies have demonstrated the ability of intracerebrally-injected GDNF to protect dopaminergic neurons and induce functional improvement in murine and primate models of PD (Gash et al., 1996; Tomac et al., 1995). To inject neurotrophic factors, a stereotactic surgery is performed after determining the precise delivery region in the brain by co-localization studies using positron emission tomography scanning of dopamine uptake and magnetic resonance imaging. Although open-label clinical studies showed positive results (Gill et al., 2003; Slevin et al., 2007), double-blind randomized clinical trials using intraventricular and intraputaminal infusion of recombinant GDNF showed mild or no therapeutic benefit and were even accompanied with distressing side effects such as nausea, vomiting, anorexia and paresthesias (Lang et al., 2006; Nutt et al., 2003). These disappointing results led the sponsor (Amgen) to terminate all GDNF clinical studies. The discrepancy between open-label and double-blind trials may be attributed to open-label study-associated subjective evaluation bias, the exact site of injection, variability of graft composition (the proportion of dopaminergic, serotonergic, 
GABAergic, substance P-containing neurons and glial cells), tissue preparation (suspension, solid tissue or strands) and/or statistical analyses.

Alternative methods of delivering GDNF include ex vivo transfected cell therapy and in vivo gene therapy. The ex vivo transfected cell therapy approach is based on implanting GDNF-expressing cells into the SNpc or striatum. Encapsulated GDNF-producing cell lines have shown therapeutic results in animal models of PD (Yasuhara et al., 2005). Furthermore, transplantation of several primary cell lines, genetically modified to express GDNF, have shown beneficial effects during in vivo animal studies (Behrstock et al., 2006; Ericson et al., 2005). To our knowledge, no clinical trials have been conducted for GDNF-secreting cells. On the other hand, in vivo gene delivery is aimed at delivering GDNF continuously to the nigrostriatal system using viral vectors. Virus-based methods of delivering GDNF circumvents the rapid metabolism of GDNF and have been shown to induce behavioral recovery in 6-hydroxydopamine- (6-OHDA)-lesioned rats (BilangBleuel et al., 1997; Mandel et al., 1997). Although some success has been achieved in animal models, clinical trials have not been warranted due to ethical and technical concerns.

\section{$\underline{\text { Neurturin }}$}

Neurturin belongs to the GDNF family of ligands and was identified as a survivalenhancing factor for sympathetic neurons (Kotzbauer et al., 1996). It shares $42 \%$ homology with GDNF and is part of a signaling pathway that involves RET-tyrosine autophosphorylation and activation of MAPK and phosphatidylinositol 3-kinase (PI3K)

(Creedon et al., 1997). Neurturin is expressed in the ventral midbrain and striatum and 
has been shown to enhance the survival of dopaminergic neurons in a fashion similar to GDNF (Horger et al., 1998).

Studies have shown the ability of cerebrally-injected neurturin to induce functional recovery in 6-OHDA-lesioned rats (Oiwa et al., 2002) and 1-methyl-4-phenyl-1,2,3,6tetrahydropyridine- (MPTP)-lesioned monkeys (Grondin et al., 2008). In addition, ex vivo transfected cell therapy, as another approach for neurturin delivery into the nigrostriatal system, via the intracerebral implantation of genetically-modified cells has been exploited. Neural stem cells (NSCs) overexpressing neurturin showed neuroprotective effects and induced functional recovery in a rat model of PD (Liu et al., 2007). Another approach to deliver neurturin continuously to the brain is in vivo viral-based neurturin gene delivery to the SNpc and has shown efficacy in protecting dopaminergic neurons of the nigrostriatal pathway in rats (Fjord-Larsen et al., 2005) and monkeys (Kordower et al., 2006).

In an open-label clinical trial, CERE120, an experimental adeno-associated virus 2 (AAV2) vector carrying the gene for human neurturin and developed by Ceregene Inc., was bilaterally injected into the putamen of 12 patients (Marks et al., 2008). No serious side effects were reported and improvement in off-medication Unified Parkinson's Disease Rating Scale (UPDRS) was observed. UPDRS is a common scoring system first developed in the 1980 s that comprehensively examines the mood, mental state, daily activities, and motor symptoms in patients in order to quantify the severity of PD. Each question used in UPDRS, that has to be answered by the patient or by the caregiver, assesses the severity of a PD symptom on a scale of $0-4(0=$ normal, $1=$ slight, $2=$ mild, $3=$ moderate, $4=$ severe). A newer version of UPDRS, revised by the movement 
disorder society, rates 65 items with a $0-4$ value whereas the older version rates 55 items, 47 with a 0-4 value and 7 items with yes or no (Goetz et al., 2008).

Following the CERE120-open label study, a double-blind randomized multicenter trial of 58 patients showed failure of bilateral intraputaminal injection of CERE-120 to reach the primary endpoint with no therapeutic differences observed between controls and treated PD patients at 12 months post-therapy. However, a longer-term follow-up study on a subgroup of the same patients revealed a modest clinical improvement at 18 months posttherapy. Additionally, subsequent post-mortem investigation on 2 patients, who died for reasons unrelated to the treatment, revealed that neurturin expression was limited to the putamen, indicating limited retrograde transport of neurturin through the degenerated nigrostriatal neurons to the SNpc. To circumvent the deficiency in retrograde transport, Ceregene has decided to initiate another CERE-120-based phase II trial that targets both the putamen and the SNpc (Marks et al., 2010). The results of the trial have not been revealed at the time of writing.

\section{$\underline{\text { Brain-derived neurotrophic factor }}$}

Brain-derived neurotrophic factor is widely expressed in the brain and plays a critical role in the axonal growth and neuronal regeneration (Lykissas et al., 2007). Whereas several studies report brain-derived neurotrophic factor to have neuroprotective effects in chemically-induced nigrostriatal dopaminergic neuron injury; it also supports neuronal maturation under homeostatic conditions (Baker et al., 2005). It acts by interacting with two receptors abundantly expressed in the nigrostriatal system, tyrosine kinase B (TrkB) and p75 neurotrophin receptor (p75NTR) (Yan et al., 1997). 
Ex vivo and in vivo strategies, for delivering brain-derived neurotrophic factor into the brain, have been investigated. Astrocytes and fibroblasts, genetically modified to express brain-derived neurotrophic factor and injected intrastriatally in a rat model of PD, resulted in functional motor improvement (Levivier et al., 1995; Yoshimoto et al., 1995). However, in vivo gene transfer of brain-derived neurotrophic factor gene into the SNpc of parkinsonian rats failed to exhibit neuroprotective properties (Klein et al., 1999; Sun et al., 2005), indicating the insufficiency of brain-derived neurotrophic factor single-gene delivery. Moreover, supraphysiological amounts of brain-derived neurotrophic factor could be associated with deleterious effect on neuronal circuits, impaired learning, and increased susceptibility to seizures (Croll et al., 1999). The mixed results observed with brain-derived neurotrophic factor therapy were not convincing enough to warrant conducting clinical studies. Besides GDNF, neurturin and brain-derived neurotrophic factor, the utility of several other growth factors, including vascular endothelial growth factor, pigment epithelium-derived factor, growth/differentiation factor 5, neurotrophin-3, neurotrophin-4/5, conserved dopamine neurotrophic factor and mesencephalic astrocytederived neurotrophic factor, in the treatment of PD has been and/or is being explored (Falk et al., 2010; Lindholm et al., 2007; Sullivan et al., 1997; Ventimiglia et al., 1995; Voutilainen et al., 2009).

Lately, the focus is shifting to implanting genetically-engineered neurotrophic factorexpressing SCs to replace dead dopaminergic neurons and simultaneously protect the remaining neurons in patients. Another potentially-effective approach is the use of small molecules to enhance the activity of endogenous neurotrophic factors. For instance, it was demonstrated that intracerebral infusion of peroxovanadium, an inhibitor of protein 
tyrosine phosphatases, can protect neurons in the SNpc of 6-OHDA-lesioned rats by enhancing the activity of endogenous neurotrophic factors on their respective tyrosine kinase-linked receptors (Yang et al., 2007). Creating small molecules that could directly activate neurotrophic factor receptors would be of great interest as well.

\section{Gene therapy}

Gene therapy in PD offers the advantage of delivering therapeutic genes into specific loci in the brain using a one-time stereotaxic surgical procedure, resulting in robust long-term gene expression. Gene therapy primarily aims at achieving one or more of the following three goals. The first goal is to boost the production of dopamine into the striatum by over-expressing dopamine synthesizing enzymes such as tyrosine hydroxylase (Zhang et al., 2004) and aromatic L-amino acid decarboxylase (AADC) (Li et al., 2006). The second goal is to protect the remaining dopaminergic neurons in the basal ganglia by utilizing genes of neurotrophic factors such as GDNF (Akerud et al., 2001) and neurturin (Fjord-Larsen et al., 2005). The third goal is to modulate basal ganglia circuits through the introduction of glutamic acid decarboxylase (GAD), the enzyme that converts glutamic acid into inhibitory GABA, in the subthalamic nucleus (Emborg et al., 2007). AAV and lentiviruses (LV) are typically used to introduce the genes of interest into the striatum, SNpc or subthalamic nucleus cells of PD patients, using direct stereotaxic injections. AAV vectors are preferred in PD clinical trials due to their low immunogenicity and ability to induce potent, long-term expression of genes (Zaiss and Muruve, 2005). Similarly, LV constructs offer a safe clinical-grade alternative to deliver genes into non-dividing cells in neurodegenerative disorders (Lundberg et al., 2008). 
The gene coding for tyrosine hydroxylase is the first gene to be investigated in the quest for a gene therapy of $\mathrm{PD}$, and has shown promising results in vitro and in vivo (Kang et al., 2001). Further, levels of AADC, the enzyme that catalyzes the decarboxylation of levo-dopa and converts it to DA, are diminished in the brains of PD patients. Indeed, AADC gene therapy has been shown to improve motor functions in MPTP-lesioned primates (Bankiewicz et al., 2006). These results led to the initiation of phase I clinical trials. Ten PD patients were treated with bilateral intraputaminal injection of human AADC-carrying AAV vector and displayed approximately $30 \%$ improvement in the onmedication (at day times of drug peak plasma concentration such as one hour after taking a drug dose) and off-medication (at day times of lowest drug plasma concentration such as early morning) states based on the UPDRS. However, headaches and increased risks of cerebral hemorrhage were reported as side effects (Christine et al., 2009). Another phase I clinical study employing AAV-mediated intraputaminal delivery of AADC carried out in 6 PD patients were well tolerated and $46 \%$ improvement in functional performance in the off-medication state, based on the UPDRS scores was reported (Muramatsu et al., 2010).

A combinatorial approach involving infusion of the three main enzymes required in dopamine synthesis, viz. TH, guanosine triphosphate (GTP) cyclohydrolase 1, and AADC using a tricistronic LV vector resulted in significantly higher motor recovery in primate models of PD, compared to single gene delivery (Jarraya et al., 2009; Muramatsu et al., 2002). GTP cyclohydrolase 1 is an enzyme needed to convert GTP to tetrahydrobiopterin (BH4), a cofactor involved in the tyrosine hydroxylase-catalyzed production of levo-dopa from L-tyrosine (Levine et al., 1981). Pre-published reports on a 
currently ongoing phase I/II clinical trial, that implements a similar combinatorial strategy, revealed motor improvement in UPDRS scores in all cohorts at 6 months post therapy (Oxford BioMedica, 2011), highlighting the advantage of combinatorial approaches over single gene delivery. A schematic representation of the tricistronic approach is shown in figure 2 .

\section{TH \\ $\mathrm{AADC}$ \\ $\mathrm{GCH} 1$}

LV

Prosavin

Figure 2. A tricistronic approach using the three genes responsible for dopamine synthesis, tyrosine hydroxylase, aromatic amino acid decarboxylase and GTP cyclohydrolase 1, has been investigated in PD patients. (TH: tyrosine hydroxylase, AADC: aromatic amino acid decarboxylase, GCHI: GTP cyclohydrolase 1, LV: lentivirus, Prosavin: the brand name of the preparation)

Since PD pathology is associated with overactivity of the subthalamic nucleus and the globus pallidus pars interna (Hammond et al., 2007), it was hypothesized that inhibiting the subthalamic nucleus through introduction of the GAD gene that converts glutamic acid into GABA, the major inhibitory transmitter in the CNS, will alleviate the symptoms of PD (figure 3). Indeed, functional improvements have been reported following AAV2mediated delivery of GAD gene in murine (Lee et al., 2005) and primate (Emborg et al., 2007) models of PD, leading to the commencement of clinical trials. In a phase I trial of unilateral infusion of the GAD-viral vector into the subthalamic nucleus, no adverse effects were reported and significant motor improvements were observed up to 12 months post-treatment (Kaplitt et al., 2007). In addition, a recent double-blinded clinical trial implementing the AAV2-mediated bilateral subthalamic nucleus delivery of GAD showed positive results with a $23.1 \%$ mean improvement of UPDRS motor score in the 
off-medication state, compared to $12.7 \%$ in the control group at 6 months post-treatment (LeWitt et al., 2011). These results are probably the most promising results observed in a controlled double-blinded trial in the search for an effective gene therapy for PD. However, the improvement shown in the GAD-delivery study seem to be approximately half of what was observed with surgical deep brain stimulation (Limousin et al., 1998), raising skepticism about the future of gene-therapy approaches in PD.

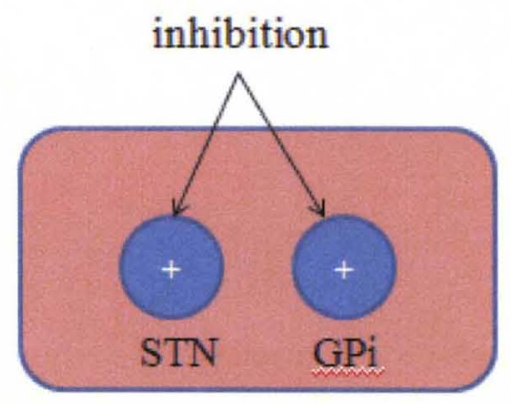

Figure 3. Inhibiting the subthalamic nucleus (STN) and/or the globus pallidus interna via deep brain stimulation or via delivery of glutamic acid decarboxylase encoding gene is useful to treat PD.

Taken together, these studies indicate the potential for using gene therapy to treat PD in the future. However, improved long-term stable expression of target gene as well as confirmation of their safety are required for the success of effective and safe genetherapy approaches in the treatment of PD. 


\section{CHAPTER III}

\section{CELL REPLACEMENT THERAPY FOR PD}

The failure of known pharmacological and surgical measures to halt and/or reverse the progressive loss of neurons and the associated pathophysiology in PD patients makes it imperative to search for novel therapeutic approaches. Cell replacement therapy appears to be promising in this regard as it offers a means to replace degenerative dopaminergic neurons, especially in the SNpc, where the initial neurodegeneration occurs in PD (Chiu and Hall, 2006). Double-blind placebo-controlled clinical trials that implemented the intracerebral implantation of human dopaminergic neurons-containing grafts in several PD patients (Freed et al., 2001; Olanow et al., 2003) provided proof-of-principle for the potentials of cell replacement therapy in PD, albeit with a few remaining challenges.

\section{Tissue grafts}

The earliest cell replacement therapy for PD employed autologous chromaffin cellcontaining adrenal medulla tissue and was reported as a success when grafted in 2 PD patients (Madrazo et al., 1987). Subsequently, hundreds of patients were grafted based on the same approach. However, the grafts were found to be a failure due to the associated morbidity and the lack of significant behavioral recovery (Goetz et al., 1991).

The trend then shifted toward grafting fetal mesencephalic tissue collected from 8- to 9week-old fetuses (Lindvall et al., 1990). The first clinical trials implementing fetal tissue 
grafting was carried out more than twenty years ago and showed promising recovery in some patients (Lindvall et al., 1990). Furthermore, fetal mesencephalic graft neurons survived in the host striatum for a long period of time and induced positive motor improvement (Hagell et al., 1999; Hauser et al., 1999). In fact, some patients improved satisfactorily for more than ten years after the transplantation (Mendez et al., 2008). However, double-blind fetal midbrain grafting studies sponsored by the National Institute of Health (NIH) showed variable effects as well as induction of distressing side effects such as graft-induced dyskinesia. Indeed, graft-induced dyskinesia was reported in $56 \%$ of the treated subjects and some cases necessitated surgical intervention by deep brain stimulation (Freed et al., 2001; Olanow et al., 2003). Advanced PD patients with widespread neurodegeneration outside the nigrostriatal system and those with a history of levo-dopa-induced dyskinesia are more likely to experience graft-induced dyskinesia. Hence, it is imperative to apply strict inclusion criteria that avoid patients with high risk of developing graft-induced dyskinesia (Wakeman et al., 2011). The cause of the dyskinesia is likely the "overload" due to excess dopamine secretion into the striatum and/or the unavoidable presence of serotonergic neurons within the fetal ventral mesencephalic grafts (Lane et al., 2010). In fact, serotonergic neuron-rich grafts do not exert therapeutic effect and cause deterioration of levo-dopa-induced dyskinesia in a rat model of PD (Carlsson et al., 2007). Moreover, a 2:1 ratio of dopaminergic neurons to serotonergic neurons markedly reduced levo-dopa induced dyskinesia, indicating that the relative ratio of dopaminergic neurons to serotonergic neurons (not the absolute number of serotonergic neurons) is what drives dyskinesia (Carlsson et al., 2009). Interestingly, systemic administration of buspirone, a serotonergic receptor 5-HT1A agonist that 
dampen transmitter release from serotonergic neurons, markedly attenuated graft-induced dyskinesia (Politis et al., 2010). Hence, it is recommended to exclude, as much as possible, serotonergic neurons from transplants. Moreover, standardization of the parameters for graft collection, preparation and storage is needed to control the dopaminergic: serotonergic composition of grafted tissues.

Importantly, detection of cellular PD-related pathological features in a few grafted cells in the brains of treated patients, ten years after transplantation (Kordower et al., 2008; Li et al., 2008), led to the conclusion that the surrounding brain microenvironment has a deleterious effect on the survival of grafted and endogenous dopaminergic neurons in PD patients. This report was contradicted by another study which did not detect any pathological features in the grafted neurons (Mendez et al., 2008). Nevertheless, ethical concerns as well as issues associated with the availability of 8-9 week old fetal tissue made it impractical to continue investigating fetal midbrain-derived grafts in clinical therapy (Astradsson et al., 2008; Deierborg et al., 2008), raising the need for more practical sources for cell replacement therapy in PD.

\section{Stem cells (SCs) as a source of cell replacement therapy in the treatment of PD}

The ethical and practical impediments associated with fetal grafting in PD shifted the attention of the cell replacement therapy field to the use of SCs, widely viewed as a therapeutic strategy with immense potential in the treatment of neurodegenerative diseases. The general strategy is to harvest SCs and induce them to differentiate into

dopaminergic neurons that could be transplanted in the brain to replace, protect or repair 
endogenous dopaminergic neurons in the $\mathrm{SNpc}$ in order to halt and/or reverse the progressive nature of the disease.

Over the past decade, several types of SCs have been investigated as potential candidates for cell replacement therapy in PD, including pluripotent embryonic SCs (ESCs), induced pluripotent SCs (iPSCs), and multipotent neural (N) and mesenchymal (M) SCs. Pluripotent SCs, such as ESCs, give rise to all cell types within the three germ layers, whereas multipotent tissue-specific SCs such as NSCs give rise to all cell types within their respective tissue. There is some evidence that multipotent SCs possess the ability to transdifferentiate when given the right conditions, albeit with little efficiency (Cogle et al., 2004; Priller et al., 2001), indicating the possibility of using non-neural multipotent SCs, such as MSCs, to induce dopaminergic neuronal differentiation in the treatment of PD. A summary of the different types of stem cells investigated in the treatment of PD and their advantages and disadvantages are presented in table 1. 
Table 1. Summary of the advantages and disadvantage of stem cells ins estigated in the treatment of PI).

\begin{tabular}{|c|c|c|c|c|}
\hline Type & potency & Main source & Advantages & Disadvantages \\
\hline $\begin{array}{l}\text { embryonic } \\
\text { stem cells }\end{array}$ & pluripotent & embryonic blastocyst & $\begin{array}{l}\text { - high dopaminergic } \\
\text { yield } \\
\text { - effective in animal } \\
\text { models }\end{array}$ & $\begin{array}{l}\text { - tumorigenic } \\
\text { - ethical issues } \\
\text { - poor survival in vivo }\end{array}$ \\
\hline $\begin{array}{l}\text { induced } \\
\text { pluripotent } \\
\text { stem cells }\end{array}$ & pluripotent & $\begin{array}{l}\text { reprogrammed } \\
\text { somatic cells }\end{array}$ & $\begin{array}{l}\text { - autologous } \\
\text { transplantation } \\
\text { - no ethical issues } \\
\text { - effective in animal } \\
\text { models }\end{array}$ & $\begin{array}{l}\text { - low dopaminergic } \\
\text { yield } \\
\text { - time consuming } \\
\text { - labor intensive } \\
\text { - costly } \\
\text { - tumorigenic } \\
\text { - poor survival in vivo }\end{array}$ \\
\hline $\begin{array}{l}\text { mesenchymal } \\
\text { stem cells }\end{array}$ & multipotent & $\begin{array}{l}\text { bone marrow and } \\
\text { umbilical cord }\end{array}$ & $\begin{array}{l}\text { - autologous } \\
\text { transplantation } \\
\text { - possess anti- } \\
\text { inflammatory properties } \\
\text { - not tumorigenic } \\
\text { - safe } \\
\text { - effective in animal }\end{array}$ & $\begin{array}{l}\text { - low dopaminergic } \\
\text { yield } \\
\text { - poor survival in vivo }\end{array}$ \\
\hline $\begin{array}{l}\text { neural stem } \\
\text { cells }\end{array}$ & multipotent & adult brain & $\begin{array}{l}\text { - autologous } \\
\text { transplantation } \\
\text { - differentiate into the } \\
\text { three lineages of the } \\
\text { nervous system } \\
\text { - effective in animal } \\
\text { models }\end{array}$ & $\begin{array}{l}\text { - low dopaminergic } \\
\text { yield } \\
\text { - poor survival in vivo } \\
\text { - hard to identify and } \\
\text { isolate } \\
\text { - tumorigenic }\end{array}$ \\
\hline
\end{tabular}




\section{IIa. Embryonic Stem Cells}

ESCs are derived from the inner cell mass of the blastocyst (figure 4) and are characterized by self-renewal (indefinite proliferation while maintaining their identity), and pluripotency (ability to differentiate into all cells of the three germ layers). The main advantages of ESCs as a source for cell replacement therapy in PD are their pluripotency and high rate of proliferation (Newman and Bakay, 2008). So far, among all types of SCs, ESCs have yielded the most promising results in terms of their efficiency to differentiate into dopaminergic neurons. In fact, protocols for inducing dopaminergic neuronal differentiation of SCs have mostly been developed using ESCs (Perrier et al., 2004; Schulz et al., 2004; Yan et al., 2005).
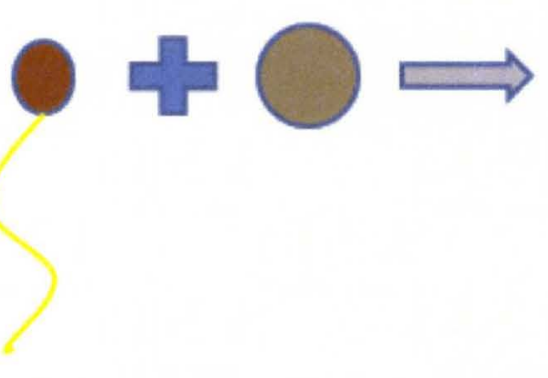
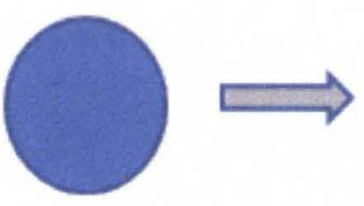

Zygote

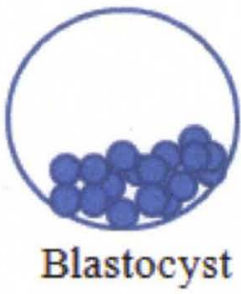

Blastocyst

Figure 4. When the zygote is formed during conception, it starts to divide rapidly and forms the blastocyst. Embryonic stem cells are derived from the inner cell mass of the blastocyst.

To achieve best results, ESCs must give rise to A9-subtype midbrain dopaminergic neurons that could replace or prevent the progressive loss of dopaminergic neurons in the SNpc region of PD patients (Mendez et al., 2005). Hence a major focus has been placed on inducing ESCs to differentiate into dopaminergic neurons before injecting them into 
the patient midbrain. The differentiation of SCs into dopaminergic neurons is promoted by culturing them on stromal feeder layers (Kawasaki et al., 2000), in the presence of specific dopaminergic neuronal fate-driving growth factors such as sonic hedgehog (SHH) (a regulator of cell division and organogenesis) and FGF8 (Lee et al., 2000), and/or through the expression of transcription factors such as Lmx1a and Nurr1 (transcription factors that play an active role in the differentiation of midbrain precursors into dopaminergic neurons) (Andersson et al., 2006; Kim et al., 2002). Not only do growth factors promote neuronal differentiation but they also potentiate the survival rate of grafted cells, thus inducing better functional recovery in animal models of PD. For instance, adding FGF2, FGF20 and Wnt5a to parthenogenetic primate SCs at their final stages of differentiation enhance survival of the grafted cells and consequently, improve motor function in 6-OHDA-lesioned rats (Sanchez-Pernaute et al., 2008). The highest differentiation efficiency has been achieved using genetically-modified Nurrloverexpressing mouse ESCs, co-cultured with PA6 stromal cells in a medium enriched with shh, fgf8 and ascorbic acid (Kim et al., 2006). The study resulted in $~ 90 \%$ dopamine-secreting neurons that integrated successfully upon transplantation in the brain of a rat model of PD.

In vivo studies have revealed the ability of ESCs to differentiate efficiently into dopaminergic neurons which in turn could be used to treat parkinsonian symptoms in animal models. For instance, upon transplantation of ESC-derived dopaminergic neurons in the striatum of unilaterally 6-OHDA-lesioned rats, Rodriguez-Gomez et al. confirmed appropriate dopamine release and reuptake by the transplanted cells as well as their ability to stimulate postsynaptic dopaminergic D2 receptors (Rodriguez-Gomez et al., 
2007). Importantly, the study showed that the implanted dopaminergic neurons survived for 32 weeks after transplantation and induced marked behavioral recovery. Similarly, over $70 \%$ reductions in chemical-induced rotational behavior and improved motor function were observed when ESC-derived dopaminergic neurons were implanted intrastriatally in a rat model of PD (Barberi et al., 2003). In primates, ESCs co-cultured with PA6 cells in the presence of FGF2 and FGF20 differentiated successfully into dopaminergic neurons, that survived in the brain and improved neurological deficits upon transplantation in the striatum of MPTP-lesioned monkeys (Takagi et al., 2005).

Whereas the aforementioned studies show marked behavioral recovery in animal models of PD when transplanted with non-human neurons, use of human (h) ESC-derived dopaminergic neurons have yielded less encouraging results, probably due to histocompatibility issues. Groups who transplanted dopaminergic neurons derived from hESCs into the brains of hemiparkinsonian rats have reported either no therapeutic effect (Brederlau et al., 2006; Park et al., 2005) or modest functional improvement (Ben-Hur et al., 2004). Although Roy et al. reported long-term survival of many brain-grafted hESCderived cells in addition to a significant functional recovery in a rat model of PD (Roy et al., 2006), subsequent studies questioned the results and conclusions drawn from the study and have suggested that the behavioral improvement observed was not dopaminedependent but probably due to graft-induced striatal damage (Morizane et al., 2008). More recently however, Kriks et al. were able to extend the in vivo survival of midbrain dopaminergic neurons derived from hESCs up to 5 months and these neurons were able to induce significant motor improvement in parkinsonian mice, rats and monkeys (Kriks et al., 2011). This group proposed a novel protocol for deriving human dopaminergic 
neurons from ESCs that recapitulated physiological conditions of dopaminergic neuronal development, thereby enhancing their long-term survivability both in vitro and in vivo.

Several challenges are still facing the clinical application of ESC-based therapy in PD patients. To our knowledge, almost all previous investigations have reported poor survival of hESC-derived neurons following transplantation (Brederlau et al., 2006; Park et al., 2005), probably due to immunological rejection by the host tissues (Toriumi et al., 2009). To circumvent this issue, some studies emphasize the importance of identifying the optimal developmental stage of ESC-derived cells before transplantation. In this regard, dopaminergic neuronal precursors are thought to be more capable of avoiding the premature death of cells after transplantation as compared to the mature dopaminergic neurons (Jonsson et al., 2009). Moreover, ethical concerns associated with the use of cells obtained from human embryos for cell replacement therapy have made clinical application of ESCs difficult (Fukuda and Takahashi, 2005).

In addition to the aforementioned impediments, the risk of teratoma (potentially fatal benign tumors containing a mixture of tissue types, formed after injection of SCs in animal models) formation after transplanting ESC-derived transplants poses the greatest challenge to clinical cell replacement therapy for PD patients. In fact, human ESCs share many cellular and molecular similarities with cancer cells such as high proliferative potential (Amit et al., 2000), genomic instability (Harrison et al., 2007), epigenetic status (Calvanese et al., 2008), and high telomerase activity (Hiyama and Hiyama, 2007). Therefore, it is generally accepted that in vitro differentiation of ESCs into more mature dopaminergic precursors or neurons must be carried out before grafting. Furthermore, 
excluding all undifferentiated ESCs before transplantation is essential to avoid the formation of teratomas.

A number of approaches have been proposed to eliminate undifferentiated ESCs. For instance, fluorescence-activated cell sorting (FACS) techniques have been implemented to exclude undifferentiated SCs and neural precursors based on cell surface markers (Fukuda et al., 2006). A second approach to eliminate pluripotent cells involves killing them through the use of cytotoxic antibodies (Tan et al., 2009) or induction of selective apoptosis of undifferentiated cells through the use of the ceramide analogue, N-oleoyl serinol (S18) (Bieberich et al., 2004). A third approach involves Cripto, a protein known to inhibit ESCs differentiation and enhances tumorigenicity after transplantation. Indeed, Cripto knockout ESCs have been shown to differentiate successfully into dopaminergic neurons without inducing tumorigenesis when implanted into 6-OHDA-lesioned rats (Parish et al., 2005). Novel approaches based on studies addressing the molecular basis of tumorigenesis will enable suppression of tumorigenic genes in ESC-derived neurons in transplantation therapy.

\section{IIb. Induced Pluripotent Stem Cells}

The discovery of iPSCs has presented an invaluable source for cell replacement therapy that avoids the ethical issues associated with the use of ESCs. The general concept of using iPSCs in the treatment of PD is to reprogram the patient's own adult somatic cells into a pluripotent state and then induce them to differentiate into dopaminergic neurons that could be transplanted into the patient's brain (figure 5). Mouse somatic fibroblasts were the first to be reprogrammed into iPSCs through retroviral transduction of four 
transcription factors, namely octamer-binding transcription factor 4 (Oct4), SRY boxcontaining gene 2 (Sox2), Kruppel-like factor 4 (Klf4), and c-Myc (Takahashi and Yamanaka, 2006; Wernig et al., 2007). In addition to fibroblasts, several other cell lineages have subsequently been reprogrammed into a pluripotent state by overexpressing some or all of the aforementioned four transcription factors (Golestaneh et al., 2009; Kunisato et al., 2010; Yamanaka et al., 2008). Newer reprogramming protocols such as methods requiring no viral integration as well as strategies using small molecules to promote reprogramming efficiency are being developed to enhance the clinical potential of iPSCs, raising the possibility that they may replace ESCs in cell replacement therapy in the near future (Nishikawa et al., 2008; Wernig et al., 2008; Yamanaka, 2008).

The iPSCs are similar but not identical to ESCs in morphology, proliferative potential, telomerase activity, cell surface markers, gene expression, and epigenetic status (Kim et al., 2010; Takahashi et al., 2007). Although microarray studies have shown that iPSCs exhibit a gene-expression profile that is similar to ESCs (Hochedlinger and Plath, 2009), they are less robust than ESCs in terms of differentiation potential and effectiveness in cell replacement therapy. In fact, an increased body of literature shows that iPSCs exhibit their own unique gene expression and DNA methylation pattern that are different from ESCs (Chin et al., 2009; Doi et al., 2009). These small differences might be attributed to the genomic integration of reprogramming transcription factor genes or to the unique genetic makeup of the cells prior to reprogramming. 


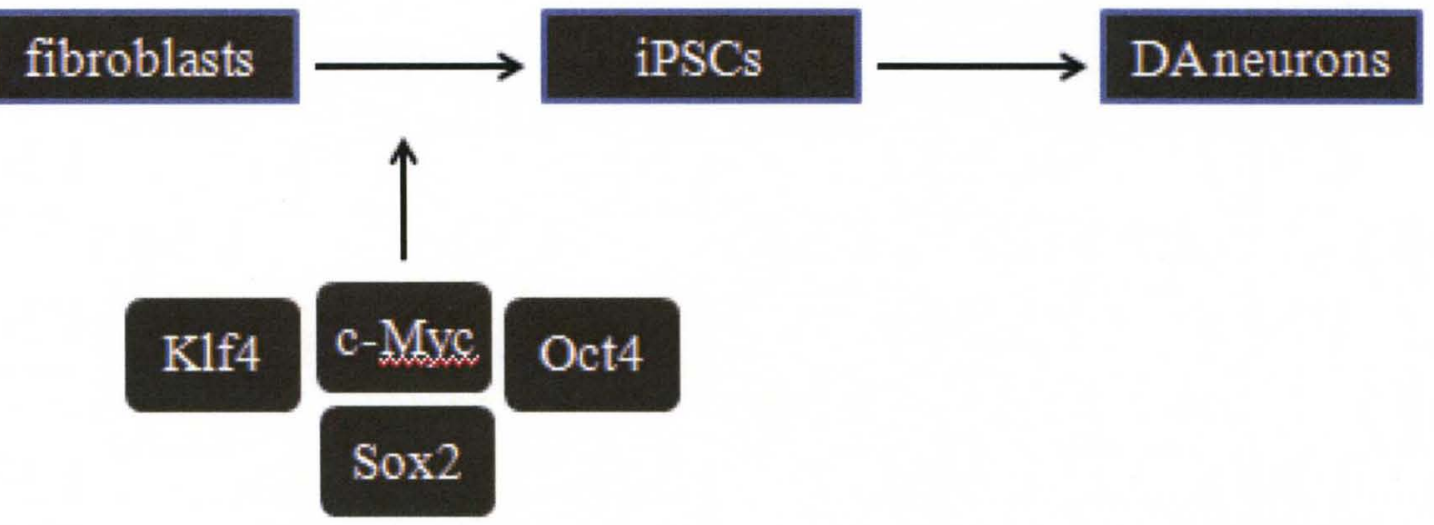

Figure 5. Transduction of four transcription factors into fibroblasts results in the formation of induced pluripotent stem cells which can subsequently be induced to differentiate into dopaminergic neurons to replace degenerated neurons in Parkinson's disease.

The iPSC technology offers a number of advantages for cell replacement therapy in PD. First, it avoids the ethical controversies associated with the use of ESCs in cell replacement therapy for PD. Furthermore, the use of iPSCs makes it feasible to carry out autologous transplantation, thereby eliminating the risk of graft rejection by the recipient immune system (Dimos et al., 2008; Park et al., 2008b). In fact, iPSCs obtained from PD patients have been shown to differentiate as efficiently as healthy individual-derived iPSCs and displayed no PD-related pathological features in vitro (Soldner et al., 2009). When PD patient's iPSC-derived cells were intrastriatally transplanted in a murine model of PD, substantial attenuation of motor deficits were observed up to 16 weeks after transplantation (Hargus et al., 2010). Although further studies are needed to establish their long-term functionality, these exciting observations highlight the curative potential of iPSCs and justify their use as a viable cell replacement strategy in the treatment of PD. Several in vivo studies have shown promising results with the use of iPSCs in the treatment of PD. For instance, Wernig et al. managed to promote the differentiation of 
iPSCs into neuronal precursors and dopaminergic neurons in vitro. Following subsequent in vivo implantation, iPSC-derived cells migrated into several brain tissues, integrated properly, and improved behavioral recovery in 6-OHDA-lesioned rats. Although initial observations showed the occurrence of teratomas in the grafted areas, depletion of all undifferentiated cells using FACS resulted in functional improvement without tumor formation up to 8 weeks after transplantation (Wernig et al., 2008). More recently, Swistowski et al. were successful in generating dopaminergic neurons from human (h)iPSCs, and the intracerebrally transplanted neurons survived and improved parkinsonian symptoms in a rat model of PD (Swistowski et al., 2010). Similar results were obtained by Cai et al. by transplantation of commercially available hiPSCs linederived dopaminergic progenitor cells into the brains of 6-OHDA-lesioned rats (Cai et al., 2010).

As with any new emergent technology, the iPSC technology also suffers from several technical and safety limitations that hinder its clinical use in patients with PD. For example, progenitors derived from hiPSCs are prone to earlier senescence than those from hESCs (Feng et al., 2010). Furthermore, compared to hESCs, hiPSCs differentiate into midbrain dopaminergic neurons with very low efficiency, rendering the clinical application of iPSCs costly and impractical. The low dopaminergic yield obtained from iPSCs may be attributed to the activation of anti-reprogramming or tumor-suppressive cellular mechanisms (Chen et al., 2011). In addition, integration of viral genomic material in the iPSCs may also play a role in altering their differentiation potential.

Due to their pluripotent potential, engrafted iPSCs also exhibit a tendency to generate teratomas comprised of the three fetal germ layers (Takahashi et al., 2007; Takahashi and 
Yamanaka, 2006). In fact, several recent reports indicate a higher tumorigenicity risk associated with iPSCs than with ESCs (Gutierrez-Aranda et al., 2010; Ohm et al., 2010). In addition to pluripotency-related tumorigenesis, tumor formation may also occur as a result of genomic integration of the viral vector DNA into the iPSCs and/or due to the mitogenic properties of the transcription factors used in reprogramming (Gottweis and Minger, 2008). In fact, two of the four reprogramming transcription factors, namely cMyc and Klf4, are oncogenic and several protocols have been proposed to minimize or avoid their use in reprogramming. Fortunately, c-Myc-free reprogramming protocols have been tested and proven successful in generating iPSCs, albeit slower and less efficient (Nakagawa et al., 2008). Furthermore, Oct4 and Sox2 are sufficient for reprogramming human fibroblasts without the need for c-Myc or Klf4, when valproic acid, a histone deacetylase inhibitor, was present (Huangfu et al., 2008). These observations, together with the potential use of small molecules in generating iPSCs, raise the possibility of minimizing or eliminating the need for oncogenic factors in cell reprogramming.

Since the use of integrating retroviruses in reprogramming is also associated with tumorigenicity (Yu et al., 2007), attempts have been made to generate iPSCs through the use of nonviral or nonintegrating viral vectors, albeit with lower efficiency. Jia et al. used DNA minicircle vectors, supercoiled molecules primarily composed of eukaryotic expression cassette, to generate transgene-free iPSCs from human adipose SCs (Jia et al., 2010). The resulting minicircle iPSCs subclones showed a high degree of similarity to hESCs in global gene expression with no genomic integration of the transgenes. However, the reprogramming efficiency achieved $(\sim 0.005 \%)$ was lower than that of viral- 
based reprogramming $(\sim 0.01 \%)$. In addition, removing reprogramming transcription factors after reprogramming using Cre-recombinase excisable viruses has been accomplished (Soldner et al., 2009). The resultant factor-free hiPSCs maintained a pluripotent state and showed an overall transcription profile closely related to hESCs rather than that of transgenic hiPSCs. More recently, induction of iPSCs was achieved through the use of protein-based programming without the need for gene-manipulation (Cho et al., 2010). The study proposed that transfer of ESC-derived proteins into mouse fibroblasts could result in reprogramming to a pluripotent state without the risk of tumorigenicity associated with the use of exogenous transcription factors. Other nonviral or nonintegrating viral vectors recently used to generate iPSCs include non-integrating adenoviruses (Stadtfeld et al., 2008), plasmids (Okita et al., 2008), episomal vectors (Yu et al., 2009), synthetic modified mRNA (Warren et al., 2010), piggyBac transposition (Woltjen et al., 2009), and miRNA (Anokye-Danso et al., 2011). Selected methods for reprogramming cells into iPSCs are presented in table 2 .

Table 2, Some methods for reprogramming human and murine somatic cells into iPSCs and their efficiencies, if available.

\begin{tabular}{|c|c|c|c|}
\hline Source of iPSCs & Reprogramming method & $\begin{array}{l}\text { Reprogramming } \\
\text { efficiency }\end{array}$ & Refs. \\
\hline $\begin{array}{l}\text { human and embryonic } \\
\text { somatic cells }\end{array}$ & $\begin{array}{l}\text { miRNA-mediated } \\
\text { reprogramming }\end{array}$ & $\geq 0.1 \%$ & $\begin{array}{l}\text { Anokye-Danso et al., } \\
2011\end{array}$ \\
\hline $\begin{array}{l}\text { human adipose stem } \\
\text { cells }\end{array}$ & $\begin{array}{l}\text { nonviral DNA minicircle } \\
\text { vectors carrying } O C T 4, \text { SOX } 2 \text {, } \\
N A N O G \text {, and LIN28 }\end{array}$ & $0.005 \%$ & Jia et al., 2010 \\
\hline $\begin{array}{l}\text { multiple human cell } \\
\text { types }\end{array}$ & synthetic modified mRNA & $1.4 \%$ & Warren et al., 2010 \\
\hline $\begin{array}{l}\text { mouse cardiac } \\
\text { fibroblasts }\end{array}$ & protein-based reprogramming & & Cho et al., 2010 \\
\hline
\end{tabular}




\begin{tabular}{|c|c|c|c|}
\hline $\begin{array}{l}\text { mouse adult bone } \\
\text { marrow mononuclear } \\
\text { cells }\end{array}$ & $\begin{array}{l}\text { retroviral transduction of } o c t 4 \text {, } \\
\text { sox } 2, k l f 4 \text {, and } c-m y c\end{array}$ & $0.067 \%$ & Kunistao et al., 2010 \\
\hline human adult testes & $\begin{array}{l}\text { embryonic stem cell medium } \\
\text { enriched with appropriate } \\
\text { growth factors (basic FGF) }\end{array}$ & $0.5-1 \%$ & Golestaneh et al., 2009 \\
\hline $\begin{array}{l}\text { human PD patients } \\
\text { fibroblasts }\end{array}$ & $\begin{array}{l}\text { cre-recombinase excisable } \\
\text { lentiviral viruses transducing } \\
O C T 4, S O X 2, K L F 4 \text {, and } C \text { - } \\
M Y C\end{array}$ & $0.01 \%$ & Soldner et al., 2009 \\
\hline $\begin{array}{l}\text { human PD patients } \\
\text { fibroblasts }\end{array}$ & $\begin{array}{l}\text { cre-recombinase excisable } \\
\text { lentiviral viruses transducing } \\
O C T 4, S O X 2 \text {, and } K L F 4\end{array}$ & $0.005 \%$ & Soldner et al., 2009 \\
\hline $\begin{array}{l}\text { human and murine } \\
\text { embryonic fibroblasts }\end{array}$ & $\begin{array}{l}\text { doxycycline-inducible } \\
\text { transcription factors delivered } \\
\text { by PiggyBac transposition }\end{array}$ & & Woltjen et al., 2009 \\
\hline $\begin{array}{l}\text { mouse embryonic } \\
\text { fibroblasts }\end{array}$ & $\begin{array}{l}\text { plasmids containing the } \\
\text { complementary DNA for oct } 4 \text {, } \\
\text { sox } 2, k l f 4 \text {, and } c-m y c\end{array}$ & $<0.000029 \%$ & Okita et al., 2008 \\
\hline mouse fetal liver cells & $\begin{array}{l}\text { nonintegrating adenoviruses } \\
\text { expressing oct } 4, \operatorname{sox} 2, k l f 4, \text { and } \\
c-m y c\end{array}$ & $0.0001-0.001 \%$ & Stadtfeld et al., 2008 \\
\hline human fibroblats & $\begin{array}{l}\text { retroviral transduction of } O C T 4, \\
S O X 2 \text {, and } K L F 4 \text {, in the } \\
\text { presence of valproic acid }\end{array}$ & $1 \%$ & Huangfu et al., 2008 \\
\hline human fibroblasts & $\begin{array}{l}\text { retroviral transduction of } O C T 4, \\
\text { SOX2, and } K L F 4\end{array}$ & $<0.001 \%$ & Nakagawa et al., 2008 \\
\hline $\begin{array}{l}\text { human PD patients } \\
\text { fibroblasts }\end{array}$ & $\begin{array}{l}\text { retroviral transduction of } O C T 4 \text {, } \\
\text { SOX } 2, K L F 4 \text {, and } C-M Y C\end{array}$ & & Park et al., 2008b \\
\hline $\begin{array}{l}\text { mouse somatic } \\
\text { fibroblasts }\end{array}$ & $\begin{array}{l}\text { retroviral transduction of } o c t 4, \\
\text { sox } 2, k l f 4, \text { and } c-m y c\end{array}$ & $0.05-0.1 \%$ & Wernig et al., 2007 \\
\hline
\end{tabular}

Another interesting approach to eliminate tumorigenicity of iPSCs is the direct reprogramming of somatic fibroblasts into dopaminergic neurons, thereby avoiding the formation of potentially tumorigenic pluripotent SCs (figure 6). To that end, mouse fibroblasts were directly reprogrammed in vitro to become neurons, without passing 
through a potentially tumorigenic pluripotent state, by employing the transduction of three neural-lineage-specific transcription factors Ascl1, Myt1l and Brn2 (Vierbuchen et al., 2010). The resultant neurons exhibited excitatory phenotype with cortical identity and formed functional synapses. Although the efficiency of reprogramming reached $19.5 \%$, tyrosine hydroxylase-expression was not detected, indicating that dopaminergic neurons were not induced. Nonetheless, the study paves the road for more investigations to use neural cell-fate determining proteins to directly reprogram somatic cells into dopaminergic neurons.

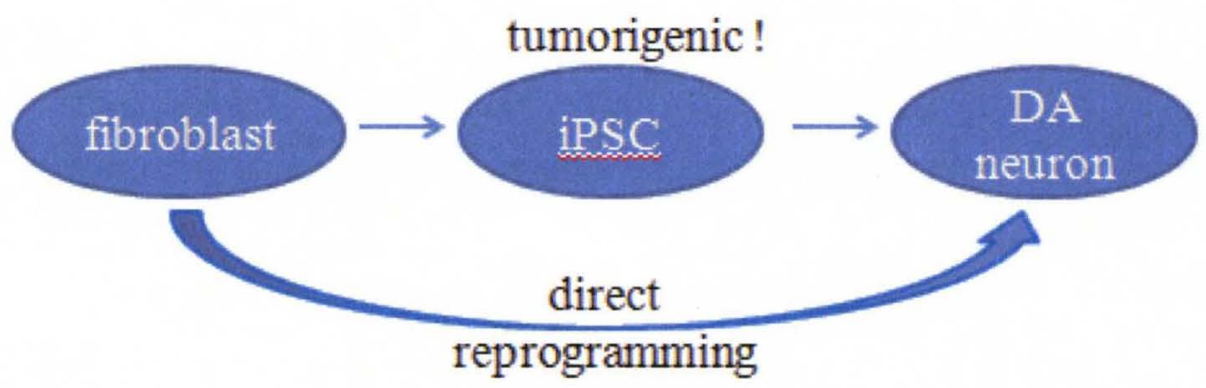

Figure 6. Direct reprogramming of fibroblasts into neurons has the advantage of avoiding the formation of tumorigenic induced pluripotent stem cells.

The iPSC technology is labor-intensive, time-consuming and costly. Increasing the efficiency of reprogramming could help reduce the cost of generating iPSCs. To that end, more efficient protocols must be developed in the near future to advance the role of iPSC-based therapy in degenerative disorders. Interestingly, a recent report has indicated that miRNA could influence cellular reprogramming and generation of iPSCs. Consequently, small molecules promoting or inhibiting specific miRNAs may prove valuable in enhancing the efficiency of cellular programming (Mallanna and Rizzino, 
2010). In addition to reducing the cost of iPSC technology, it is also imperative to understand and to circumvent the early senescence and tumorigenicity associated with iPSC-derived cells.

\section{IIc. Mesenchymal Stem Cells}

The use of MSCs in the quest for a cell replacement therapy -based treatment for PD is relatively new and less well-characterized. MSCs are responsible for generating tissues of the mesoderm and reside in adult (e.g. bone marrow, adipose tissue, peripheral blood, and liver), fetal (e.g. bone marrow, lung, spleen, liver, brain, and peripheral blood), and extraembryonic tissues (e.g. umbilical cord blood, amniotic fluid, and placenta). However, the main sources for cell replacement therapy are the umbilical cord and the adult bone marrow (Zhao and $\mathrm{Xu}, 2011$ ). The multipotent MSCs normally differentiate into mesodermal osteocytes, adipocytes, chondrocytes, and myocytes and can also give rise to neuroectodermal neurons under the right conditions in vitro (Pittenger et al., 1999; Sanchez-Ramos et al., 2000; Woodbury et al., 2000). MSCs have been shown to have inherent ability to repair neuronal damage (Phinney and Isakova, 2005), paving the road for their potential use in the treatment of PD. The use of MSCs offers multiple advantages over using other types of SCs in the treatment of PD. For instance, MSCs can be readily harvested and cultured in vitro (Bianco et al., 2001). Moreover, no ethical limitations are associated with the use of autologous MSCs as opposed to hESCs or allogeneic NSCs. MSCs are poorly immunogenic due to the lack of major histocompatibility complex (MHC)-II expression, reducing the need for immunosuppressive therapy (Morandi et al., 2008). In fact, MSCs may possess inherent immunosuppressive activity, as shown by Zhang et al. that MSCs inhibit mitogen 
stimulated $\mathrm{T}$ lymphocyte proliferation (Zhang et al., 2008). Importantly, no tumor formation or significant adverse side effects have been reported following the implantation of MSCs into the brains of PD animal models (Trzaska and Rameshwar, 2007).

A number of in vivo studies have shown the ability of MSCs to induce therapeutic behavioral improvement in murine animal models of PD (Bouchez et al., 2008; Li et al., 2001). Interestingly, human umbilical cord matrix-derived MSCs, transplanted into the brains of non-immunosuppressed murine models of PD, showed significant functional improvement with no tumor formation, confirming their immunomodulatory properties and potential for use in non-autologous transplantation (Weiss et al., 2006). Noteworthy, reports have also indicated that grafted MSCs could migrate to the site of injury and enhance the number of tyrosine hydroxylase--positive neurons in the brain (Jin et al., 2008; Sadan et al., 2009). Interestingly, even systemically-administered MSCs have been shown to promote behavioral recovery in a rat model of PD (Park et al., 2008a). This observation led to the conclusion that certain chemokines secreted from the damaged brain tissues attract MSCs to the site of brain damage.

More recently, genetically-modified MSCs have been investigated as a more robust therapeutic approach in the treatment of PD. For instance, intrastriatally transplanted vascular endothelium growth factor-expressing human umbilical cord-derived MSCs differentiated into dopaminergic neurons and ameliorated motor abnormalities in a rat model of PD (Xiong et al., 2011). Similarly, intrastriatal implantation of GDNFexpressing human bone marrow-derived MSCs in a rat model of PD resulted in the sprouting of rejuvenated tyrosine hydroxylase--positive neurons around the graft and 
significant functional improvement in parkinsonian symptoms (Glavaski-Joksimovic et al., 2010). In addition, another group reported that transplantation of brain-derived neurotrophic factor-secreting MSCs into the SNpc of a murine model of PD resulted in enhanced grafting and neuroprotection (Somoza et al., 2010).

In addition to neurotrophic factors, the dopamine synthesizing enzyme, tyrosine hydroxylase, has also been overexpressed in MSCs. When tyrosine hydoxulaseexpressing bone marrow-derived MSCs were induced to differentiate into NSCs and injected into the brain lateral ventricle of parkinsonian rats, considerable behavioral recovery was observed, indicating the ability of injected modified NSCs to migrate through the cerebrospinal fluid brain barrier into the damaged SNpc (Zou et al., 2010). Consequently, the study also highlights the possibility of less invasive approaches such as ventricular or even subarachnoid transplantation of SCs. Recently, a combination of tyrosine hydroxylase-- and GDNF-expressing MSC preparations were shown to have superior therapeutic effect than either alone when implanted into the striatum of a rat model of PD (Shi et al., 2011). This study suggests synergism between tyrosine hydroxylase and GDNF in the treatment of PD. Similar synergy has been reported when using both tyrosine hydroxylase-- and brain-derived neurotrophic factor-expressing astrocytes in animal models of PD (Wang et al., 2002). However, more conclusive studies comparing the effectiveness of normal versus genetically-modified SCs are needed.

The exact mechanism of the therapeutic effects of MSCs in neurodegenerative disorders such as PD is still controversial. Some studies indicate that MSCs exert their beneficial effect by expressing neurotrophic factors that exert neuroprotective effects on 
dopaminergic neurons (Pereira et al., 2011). Consistent with that, MSCs exhibit a unique genetic expression profile enriched in angiogenic and neurogenic genes (Secco et al., 2009). A number of reports have proposed that MSCs act by enhancing axonal growth of the dopaminergic neurons (Sasaki et al., 2009; Shen et al., 2006). In addition, the antiinflammatory effect of MSCs by reducing microglial activation has been proposed as a means for their immunomodulatory activity and thus, therapeutic effects in PD (Park et al., 2008a). Interestingly, when transplanted into the striatum of a rat animal model, MSCs showed no differentiation into dopaminergic neurons (Blandini et al., 2010). This study also showed that whereas some of the grafted MSCs differentiated into glial-like cells, the grafted cells still exerted anti-parkinsonian effect. Taken together, these results indicate that MSCs do not necessarily act by replacing dopaminergic neurons but rather by protecting the remaining dopaminergic neurons or by reversing degeneration.

Although, in vitro and in vivo animal studies have reported promising results with the use of MSCs in the treatment of PD, preliminary human clinical trials have yielded controversial results. A recent study evaluated the use of autologous bone marrow MSC transplantation in the striatum of 7 patients (Venkataramana et al., 2010). After an openlabel 12- to 36-month period of observation, only modest behavioral improvement was observed. This might have originated from a placebo effect because the magnetic resonance imaging scan did not show any differences in the brain pre- and postoperatively, indicating that the grafts may not have survived in the brain after the surgical procedure. Fortunately, no adverse effects or tumor-like formations were detected during the course of the study. This study indicates that more investigations are still needed before MSCs could be clinically employed to treat patients with PD. 


\section{IId. Neural stem cells}

NSCs are multipotent SCs present in specific areas of the brain, including the subventricular zone and the subgranular zone of the hippocampal dentate gyrus (Eriksson et al., 1998; Roy et al., 2000). However, NSCs obtained from the ventral mesencephalon are thought to differentiate more efficiently into dopaminergic neurons as compared to those harvested from other parts of the brain (Jonsson et al., 2009). Utilizing fetal or adult NSCs is thought to be a promising approach in the treatment of neurodegenerative disorders due to their potential for self-renewal and differentiation into the three cell lineages of the nervous system, viz., neurons, astrocytes, and oligodendrocytes (Gu et al., 2009; Lie et al., 2002). More importantly, NSCs are associated with lower tumorformation risks after transplantation as compared to ESCs (Morizane et al., 2008). In addition, the use of PD patient-derived NSCs paves the way for autologous transplantation and minimizes the need for immunosuppressive therapy (Arias-Carrion and Yuan, 2009). Of note, since embryonic NSCs are associated with serious ethical concerns, efforts have focused on developing methods to promote differentiation of adult NSCs into dopaminergic neurons that could be used in the treatment of PD (Trzaska and Rameshwar, 2007).

In 1998, Studer et al. first reported the generation of tyrosine hydroxylase--positive cells from embryonic rat mesencephalic precursors that exerted functional motor improvement when transplanted in a rat model of PD (Studer et al., 1998). Several subsequent studies have confirmed the potential therapeutic effects of NSCs in PD. The intrastriatally transplanted neuroepithelial SCs derived from mouse embryonic neural tube has been shown to differentiate into dopaminergic neurons and to promote functional recovery in 
6-OHDA-lesioned rats (Sun et al., 2007). In addition to their ability to differentiate into dopaminergic neurons, NSCs have been suggested to exhibit neuroprotective effects in vivo (Yasuhara et al., 2006). The study showed that supernatants from human NSC cultures exhibited neuroprotective effects on embryonic rat ventral mesencephalon dopaminergic neurons when exposed to 6-OHDA toxicity in vitro. Following transplantation into the brains of animal models of PD, most implanted human NSCs either remain undifferentiated as neural progenitors or differentiate into non-neuronal glial cells (Bjugstad et al., 2008). To overcome low dopaminergic yield of differentiating NSCs, O'Keeffe et al. overexpressed the transcription factor Pitx3 in rat embryonic NSCs derived from the ventral mesencephalon and co-cultured them with developing rat ventral mesencephalon tissue (O'Keeffe et al., 2008). The experiment showed an enhancement in the yield of A9 dopaminergic neurons in vitro and a marked functional recovery following transplantation in 6-OHDA-lesioned rats, probably due to secretion of neurotrophic factors by the developing ventral mesencephalon.

Recently, genetically-engineered rat NSCs that overexpress neurotrophin-3 were shown to be superior to non-modified NSCs in terms of regenerating dopaminergic neurons and inducing functional recovery when transplanted in a rat model of PD (Gu et al., 2009). The study also demonstrated that neurotrophin-3-expressing NSCs were able to migrate towards the damaged areas of the brain. Similarly, GDNF-expressing NSCs were shown to enhance the survival of grafted dopaminergic neurons in vivo (Ostenfeld et al., 2002), and neurturin-expressing NSCs to improve functional recovery in parkinsonian rats (Liu et al., 2007). 
However, the use of NSCs in cell replacement therapy of PD faces several practical and technical impediments. For instance, NSCs tend to lose their potential to give rise to dopaminergic phenotype following in vitro expansion and tend to differentiate primarily into glial cells in vivo (Bjugstad et al., 2008; Chung et al., 2006). Although it is generally accepted that the more differentiated SCs would exert better therapeutic effects as compared to undifferentiated SCs when transplanted in the brains of PD animal models, early senescence of mature dopaminergic neurons is still a significant issue that has to be resolved (Wang et al., 2008). In fact, when compared to murine NSCs, human NSCs have shorter telomeres indicating earlier senescence liability (Ostenfeld et al., 2000). Moreover, the effectiveness of NSCs transplantation is controversial since they already exist in the brains of PD patients. However, one could argue that they are not produced in sufficient quantities in the affected areas to halt the progressive degeneration of neurons in PD patients. Another argument is the inability of endogenous NSCs to migrate long distances to reach the damaged brain areas. Future studies should propose strategies to enhance the viability and efficiency of differentiation of NSCs into dopaminergic neurons to make their use more practical in the treatment of PD. 


\section{CHAPTER IV}

\section{DISCUSSION}

The advent of iPSC technology, together with the improved purification and differentiation procedures, have made the potential for the therapeutic use of SCs in the treatment of neurodegenerative disorders such as PD more imminent than ever. However, several issues need to be addressed before SC-based cell replacement therapy can be a clinically feasible reality in the treatment of PD.

One major obstacle facing SC-based therapy is the senescence and/or loss of cell viability of transplanted cells within few weeks following transplantation. This may be attributed to several factors including hypoxia, apoptosis, immune rejection, deficiency of trophic factors, or oxidative stress (Sonntag et al., 2005). Although the exact cause of early loss of cell viability among transplanted neurons is not well understood, a few reports have suggested the addition of exogenous factors to promote the survival of dopaminergic neurons. For instance, Sanchez-Pernaute et al. reported that exposure of primate SCs to FGF2, FGF20 and Wnt5a (a signaling protein that regulates cell fate and patterning) at the final stages of in vitro differentiation process enhanced their survival and thus resulted in improved functional recovery in a rat model of PD (Sanchez-Pernaute et al., 2008). To overcome low survival of transplanted cell, further investigations are needed to determine the proper developmental stage of SC differentiation for transplantation, 
identify the exact mechanism of early graft cell death, and propose methods to improve their survival in host tissues.

The induction of an immunological reaction against the graft could be one reason for the failure of SC therapy (Bradley et al., 2002; Drukker et al., 2002). It is therefore, useful to reduce immunological responses exerted by host tissues towards grafts by using autologous transplantation. Immune rejection may also arise from the presence of animal products during the manipulation of SCs or from allogeneic transplantation (PreynatSeauve et al., 2009), indicating the necessity for animal product-free transplants. In order to reduce allogeneic transplantation-induced rejection in clinical therapy, blood group compatible transplants should be used. Any induced trauma during the surgical implantation of SCs could also trigger an inflammatory response that may amplify MHC expression of both transplanted and recipient tissue cells (McLaren et al., 2001). When needed, the use of immunosuppressive therapy during and after surgery must be applied to reduce immune rejection and the patients must be closely monitored for compromised immunity-triggered complications.

Protocols and instruments used for the preparation of SC implants should be improved in order to guarantee purity (dopaminergic neurons and/or precursors) and safety of the SC preparations to avoid potential undesirable adverse effects. Traditionally, mouse embryonic fibroblasts have been used as a supportive feeder layer for human pluripotent SCs as they offer a cellular substrate for SC adhesion, mimicking physiological milieu, and release suitable nutrients into the medium to support self-renewal and survival of SCs (Abraham et al., 2010). Animal-derived contamination of grafted cells may lead to the transmission of animal retroviruses and other pathogens to patients. Therefore, several 
studies have proposed several protocols to avoid the use of animal products during the culture and differentiation of SCs (Abraham et al., 2010; Lei et al., 2007; Mallon et al., 2006; Unger et al., 2008). Furthermore, SC-derived implants, considered as a therapeutic product, must be prepared aseptically during manipulation and transplantation, to eliminate the risk of infection. Even the presence of fibroblasts in a human umbilical cord-derived MSC graft yielded undesirable results in animal models of PD (Pereira et al., 2011). This study showed that the presence of fibroblasts reversed the therapeutic effects of MSCs and promoted neuronal degeneration of the basal ganglia. These authors proposed that the presence or absence of fibroblasts in implants could be the reason for contradictory results achieved by different groups assessing the efficiency of MSCs in the treatment of PD.

Transplantation of pluripotent SCs and dopaminergic progenitors is accompanied by the risk of tumorigenicity. Hence, depleting residual undifferentiated pluripotent and/or progenitor populations (figure 7 ) is crucial to prevent the potential for tumor formation (Allan et al., 2010). However, it has been shown that using FACS to enrich mouse dopaminergic neurons could result in diminished neuronal survival profile (Hedlund et al., 2008). Although it is generally accepted that the longer SCs are left to differentiate in vitro, the lower the potential for teratoma formation following transplantation (PreynatSeauve et al., 2009), differentiated cells are less stable and more difficult to manipulate. Noteworthy, recent investigations reveal a significant level of overlap in gene expression between hESC- and hiPSC-derived cells and cancer cells, suggesting that pluripotent SCderived cells may possess oncogenic potential even after differentiation (Ghosh et al., 
2011).Therefore, carrying out studies to fully understand tumor-formation pathways and identify compounds that can inhibit these pathways would prove valuable.

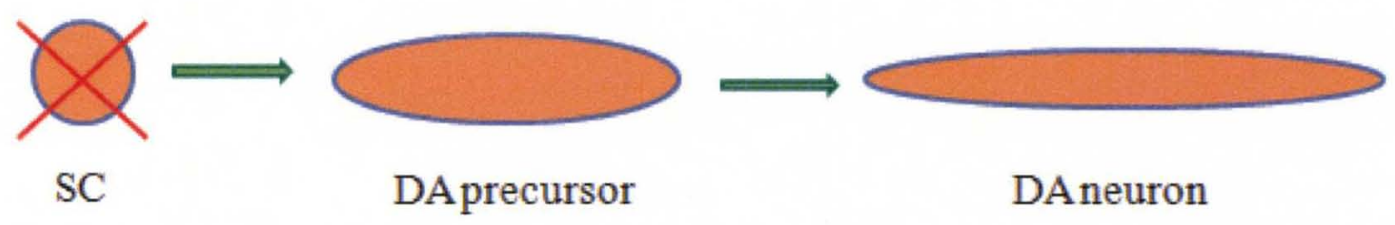

Figure 7. Elimination of all pluripotent stem cells (following differentiation) through the use of fluorescence-activated cell sorting or by inducing selective apoptosis must be carried out before transplantation in PD patients to avoid the formation of teratomas. (SC: stem cell, DA: dopaminergic)

As mentioned earlier, the brain microenvironment plays a major role in the pathology of endogenous and transplanted neurons. The microenvironment that initially led to PDassociated neuronal death may also promote degeneration of the transplanted cells. Recent investigations on patients with grafted fetalventral mesencephalon showed that transplanted cells were affected by the brain surrounding microenvironment. In fact, pathological features typically seen in degenerating dopaminergic neurons in PD were also observed in grafted neurons (Kordower et al., 2008; Li et al., 2008). While a definitive understanding of the exact role of surrounding stroma in neurodegeneration is still lacking, a study by Redmond et al. suggests that the reciprocal relationship between transplanted NSCs, that express neuroprotective factors, and the pathological microenvironment, is responsible for the functional improvement observed in primate models of PD. The authors implanted undifferentiated NSCs into the brains of MPTPtreated primates and found that while only a few of the transplanted NSCs differentiated into tyrosine hydroxylase-positive dopaminergic neurons, the vast majority of the SCs 
became growth factor-secreting astrocytes in the vicinity of the developing dopaminergic neurons (Redmond et al., 2007). These observations led to the conclusion that astrocytes secrete neurotrophic, angiogenic and anti-inflammatory factors that alter the toxic microenvironment in the damaged areas of the brain, thereby improving the parkinsonian symptoms. Consistent with these findings, NSCs have been shown to constitutively secrete specific neurotrophic factors that promote regeneration following spinal cord injury (Lu et al., 2003). Thus, the field of SC therapy should focus not only on replacing the dopaminergic neurons, but also on protecting the remaining endogenous neurons by altering the surrounding brain microenvironment.

Transplant preparation should contain enough dopaminergic progenitors and/or midbrain A9 dopaminergic neurons that would survive, communicate properly with the other neuronal circuits in the brain, and induce marked therapeutic effect for at least several months after surgery, to justify such an invasive SC-based therapy in the treatment of PD. Maintaining the right dopamine physiological levels in the basal ganglia is crucial since lower or higher concentrations will result in undesirable hypo- or hyper-kinetic manifestations. The possibility that SCs derived from PD patients may generate pathological neurons due to inherent genetic abnormalities (Park et al., 2008b) poses another major impediment for SC-based therapy. Furthermore, SC-derived preparations are permanently placed in the brain making it difficult to reverse the therapy in case the treatment resulted in serious adverse effects. The fact that other non-dopaminergic neurons such as the noradrenergic neurons of the locus coeruleus and the serotonergic neurons of the raphe nucleus could also degenerate particularly in the advanced stages of PD, further complicates cell-based therapy (Ahlskog, 2007). 
Novel animal models and novel assessments of functional recovery should be designed to better reflect the different stages of the disease and the degree of recovery after cell replacement therapy. Typically, 6-OHDA treatment is thought to induce neuronal toxicity on monoamine-secreting neurons of the brain creating a somewhat reliable murine model of PD (Przedborski et al., 1995; Ungerstedt, 1968). On the other hand, non-human primate models of PD are typically induced by injecting MPTP (Eslamboli et al., 2005; Muramatsu et al., 2009; Takagi et al., 2005). However, these chemically-induced PD models are not progressive in nature and are not associated with the formation of proteinaceous Lewy bodies as observed in human PD, raising doubts about the reliability of these models. Development of genetic and/or slowly progressive animal models of PD will offer more robust and credible simulation of the disease that can be exploited to further understand the pathophysiology of the disease and identify novel therapeutic approaches (Litvan et al., 2007a).

Several questions remain to be addressed regarding the conditions and mode of delivery of SC-derived implants. For instance, how many cells should be transplanted? Is it better to inject SC-derived cells in the SNpc or the striatum or both? The two main plausible sites of injection are the SNpc and the corpus striatum. Intrastriatal implantation of SC preparations was adopted mostly because this is where the physiological dopamine is secreted. In addition, earlier fetal mesencephalic grafting studies in PD patients had adopted the intrastriatal rather than the intranigral placement of grafts. However, some studies have stated that intranigral injection resembles more closely the normal physiological state and thus it is superior to intrastriatal placement, provided that the resulting dopaminergic neurons would be able to extend axons to the striatum and 
integrate properly with adjacent tissues (Preynat-Seauve et al., 2009). The main factors affecting the outcome of SC-based therapy in PD are shown in figure 8.

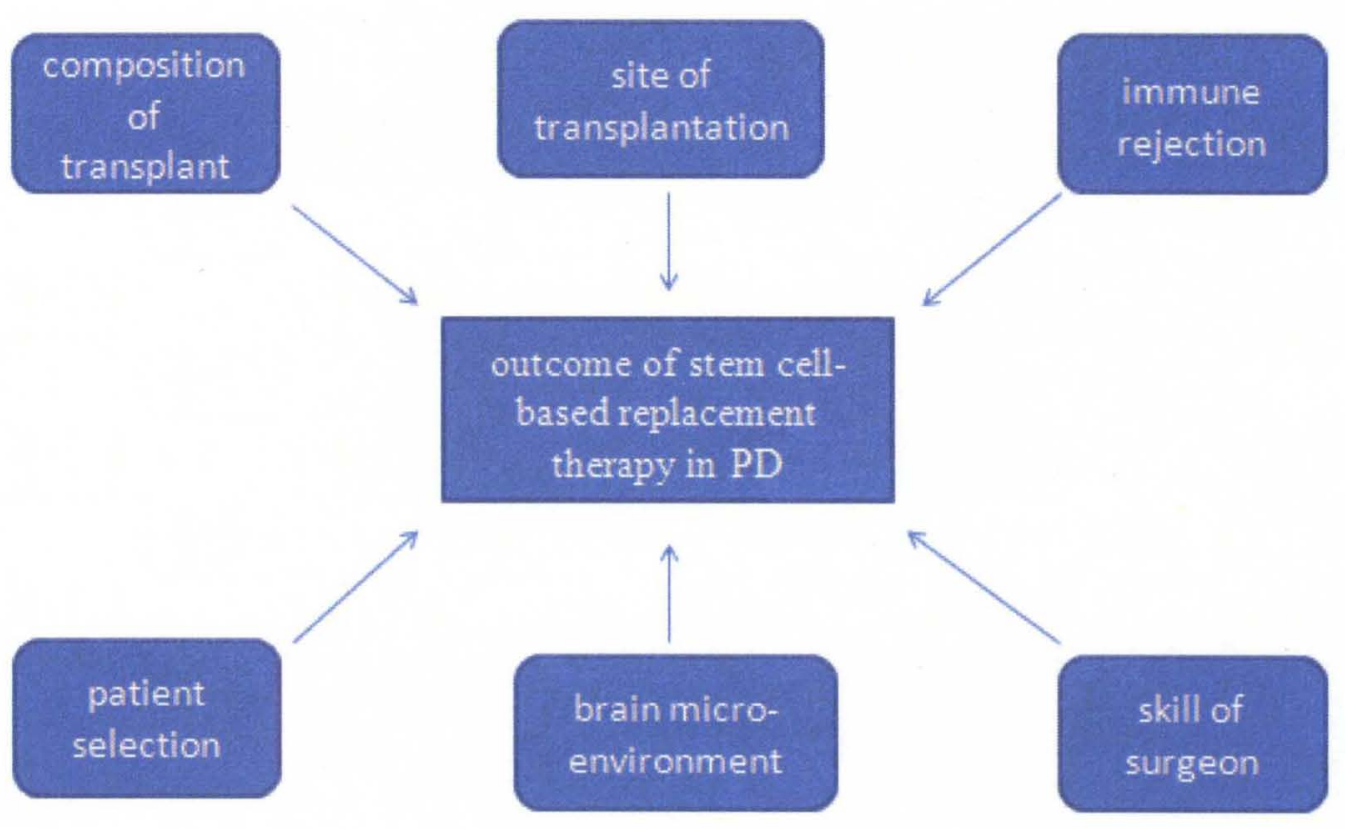

Figure 8. Factors influencing the outcome of stem cell-based replacement therapy in PD.

There is still much work to do regarding the design of clinical studies in terms of patient selection: whether these experiments should be carried out on early-, middle- or latestaged patients, and whether safety and/or efficacy are to be evaluated. Noteworthy, the possibility that transplanted SC-derived cells may dedifferentiate or migrate to unintended areas of the brain, which may affect patients' mental cognition, poses an enormous ethical obstacle in warranting clinical trials. Therefore, SC-based therapy is still largely an experimental approach with MSCs being the only type of SCs to have been analyzed in a small-sized open-label clinical trial. Finally, a recent report goes 
beyond the aforementioned concerns and limitations to suggest that the functional improvements observed in cell replacement therapy-treated PD patients are attributed to the surgery and/or the psychological effects associated rather than to the transplanted SCderived preparations. In 2000, six PD patients enrolled in a Titan Pharmaceuticalsdesigned phase I clinical trial, known as Spheramine, in which cultured human retinal epithelial cells were implanted into the brain. A year later, the patients showed a $48 \%$ improvement in motor function that largely lasted for 4 years. Later on, investigators found out that Spheramine was no more effective than placebo, suggesting that the brain surgery rather than the transplanted dopamine-secreting cells was responsible for the reported motor improvement and indicating a potential therapeutic role for sham brain surgery in the treatment of PD (Katsnelson, 2011).

Consistent with that, the placebo effect plays a prominent role in the functional improvements observed in treated PD patients through a reward-expectation mechanism which apparently results in dopamine release into the striatum (de la Fuente-Fernandez and Stoessl, 2002). In fact, the placebo group and the dopamine agonist (pergolide) treated group showed similar functional improvement $(23 \%$ and $30 \%$ after 24 weeks respectively) (Diamond et al., 1985). Further, several articles reviewed by Shetty et al reported a functional improvement following placebo treatment in PD patients, ranging from $\sim 10$ to $\sim 60 \%$ of that seen in the drug-treated group (Shetty et al., 1999). Interestingly, during a six-month study, $16 \%$ of PD subjects improved markedly on placebo-treatment, exhibiting 50\% improvement or scoring a change in at least two motor items by $\geq 2$, based on the UPDRS (Goetz et al., 2000). On the other hand, it is conceivable that the therapeutic efficacy of cell-based preparations in PD goes beyond 
mere psychological effect since their use in clinical trials were accompanied with improvements in ${ }^{18} \mathrm{~F}$-dopa uptake (an indicator of levo-dopa intake by dopaminergic neurons), profuse dopaminergic neuron re-innervation, and formation of functional synapses in the host striatum (Hagell and Brundin, 2001).

In summary, although SC-based cell replacement therapy is enticing in PD as it offers a replacement for dead neurons and a neuroprotection for the remaining functional ones, several obstacles hinder its clinical application in patients. Of all investigated impediments early senescence and the potential tumorigenicity of transplanted cells pose major challenges for the application of cell-based therapy. Moreover, the required good manufacturing practice (GMP) standards during the preparation and transplantation of the transplants in addition to the technical and practical issues associated with the application of such a sophisticated approach in an extremely sensitive organ (the brain) pose major challenges. Hence, it is obvious that SC-based therapy for PD is still at an early stage and that more investigations are needed to resolve the associated safety, efficacy and technical concerns. 


\section{CHAPTER V CONCLUSION}

PD presents a major challenge because none of the existing therapies are capable of halting and/or reversing the progressive neurodegeneration. Newer approaches involving neurotrophic factors, gene therapy and SCs are advantageous and must be further developed since they offer a modifying potential to PD pathophysiology, either by replacing and/or protecting dopaminergic neurons. Among the newer approaches, only SC-based therapies actually provide a replacement for lost dopaminergic neurons in PD. It is encouraging that this relatively new field is advancing fast, achieving significant results in animal models of $\mathrm{PD}$, albeit with a few unresolved concerns. Among these concerns, ethical issues, poor survivability of transplants and the inherent tumorigenicity of pluripotent SCs hinder further advancement of the field. It is thus imperative that intense investigations be carried out to circumvent tumorigenicity and prolong survivability. Placebo-controlled double-blind clinical trials should then be initiated in patients to establish the safety and efficacy of SC-based anti-PD therapies. Success of SC-based preparations will have implications not only in PD but also in other neurodegenerative diseases including Alzheimer's disease. Hence it is conceivable that once the current impediments facing SC-based cell replacement therapy are resolved, it will emerge as an efficacious treatment of choice in combating PD. 


\section{REFERENCES}

Abraham, S., Sheridan, S.D., Miller, B., and Rao, R.R. (2010). Stable propagation of human embryonic and induced pluripotent stem cells on decellularized human substrates. Biotechnol Prog 26, 1126-1134.

Aguado, T., Romero, E., Monory, K., Palazuelos, J., Sendtner, M., Marsicano, G., Lutz, B., Guzman, M., and Galve-Roperh, I. (2007). The CB1 cannabinoid receptor mediates excitotoxicity-induced neural progenitor proliferation and neurogenesis. J Biol Chem 282, 23892-23898.

Ahlskog, J.E. (2007). Beating a dead horse: dopamine and Parkinson disease. Neurology 69, 1701-1711.

Akerud, P., Canals, J.M., Snyder, E.Y., and Arenas, E. (2001). Neuroprotection through delivery of glial cell line-derived neurotrophic factor by neural stem cells in a mouse model of Parkinson's disease. Journal of Neuroscience 21, 8108-8118.

Allan, L.E., Petit, G.H., and Brundin, P. (2010). Cell transplantation in Parkinson's disease: problems and perspectives. Curr Opin Neurol 23, 426-432.

Amit, M., Carpenter, M.K., Inokuma, M.S., Chiu, C.P., Harris, C.P., Waknitz, M.A., Itskovitz-Eldor, J., and Thomson, J.A. (2000). Clonally derived human embryonic stem cell lines maintain pluripotency and proliferative potential for prolonged periods of culture. Dev Biol 227, 271-278.

Andersson, E., Tryggvason, U., Deng, Q., Friling, S., Alekseenko, Z., Robert, B., Perlmann, T., and Ericson, J. (2006). Identification of intrinsic determinants of midbrain dopamine neurons. Cell 124, 393-405.

Anokye-Danso, F., Trivedi, C.M., Juhr, D., Gupta, M., Cui, Z., Tian, Y., Zhang, Y., Yang, W., Gruber, P.J., Epstein, J.A., et al. (2011). Highly efficient miRNAmediated reprogramming of mouse and human somatic cells to pluripotency. Cell Stem Cell 8, 376-388.

Arias-Carrion, O., and Yuan, T.F. (2009). Autologous neural stem cell transplantation: a new treatment option for Parkinson's disease? Med Hypotheses 73, 757-759.

Astradsson, A., Cooper, O., Vinuela, A., and Isacson, O. (2008). Recent advances in cellbased therapy for Parkinson disease. Neurosurg Focus 24, E6.

Baker, S.A., Stanford, L.E., Brown, R.E., and Hagg, T. (2005). Maturation but not survival of dopaminergic nigrostriatal neurons is affected in developing and aging BDNF-deficient mice. Brain Res 1039, 177-188.

Bankiewicz, K.S., Forsayeth, J., Eberling, J.L., Sanchez-Pernaute, R., Pivirotto, P., Bringas, J., Herscovitch, P., Carson, R.E., Eckelman, W., Reutter, B., et al. (2006). Long-term clinical improvement in MPTP-lesioned primates after gene therapy with AAV-hAADC. Mol Ther 14, 564-570.

Barberi, T., Klivenyi, P., Calingasan, N.Y., Lee, H., Kawamata, H., Loonam, K., Perrier, A.L., Bruses, J., Rubio, M.E., Topf, N., et al. (2003). Neural subtype specification 
of fertilization and nuclear transfer embryonic stem cells and application in parkinsonian mice. Nat Biotechnol 21, 1200-1207.

Behrstock, S., Ebert, A., McHugh, J., Vosberg, S., Moore, J., Schneider, B., Capowski, E., Hei, D., Kordower, J., Aebischer, P., et al. (2006). Human neural progenitors deliver glial cell line-derived neurotrophic factor to parkinsonian rodents and aged primates. Gene Ther 13, 379-388.

Ben-Hur, T., Idelson, M., Khaner, H., Pera, M., Reinhartz, E., Itzik, A., and Reubinoff, B.E. (2004). Transplantation of human embryonic stem cell-derived neural progenitors improves behavioral deficit in Parkinsonian rats. Stem Cells 22, 12461255.

Bianco, P., Riminucci, M., Gronthos, S., and Robey, P.G. (2001). Bone marrow stromal stem cells: nature, biology, and potential applications. Stem Cells 19, 180-192.

Bieberich, E., Silva, J., Wang, G., Krishnamurthy, K., and Condie, B.G. (2004). Selective apoptosis of pluripotent mouse and human stem cells by novel ceramide analogues prevents teratoma formation and enriches for neural precursors in ES cell-derived neural transplants. J Cell Biol 167, 723-734.

Bilang-Bleuel, A., Revah, F., Colin, P., Locquet, I., Robert, J.J., Mallet, J., and Horellou, P. (1997). Intrastriatal injection of an adenoviral vector expressing glial-cell-linederived neurotrophic factor prevents dopaminergic neuron degeneration and behavioral impairment in a rat model of Parkinson disease. Proc Natl Acad Sci U S A $94,8818-8823$.

BioMedica, O. (2011). Oxford BioMedica Announces Interim Update On ProSavin $®$ Phase I/II Study In Parkinson's Disease (Oxford BioMedica).

Bjugstad, K.B., Teng, Y.D., Redmond, D.E., Jr., Elsworth, J.D., Roth, R.H., Cornelius, S.K., Snyder, E.Y., and Sladek, J.R., Jr. (2008). Human neural stem cells migrate along the nigrostriatal pathway in a primate model of Parkinson's disease. Exp Neurol 211, 362-369.

Blandini, F., Cova, L., Armentero, M.T., Zennaro, E., Levandis, G., Bossolasco, P., Calzarossa, C., Mellone, M., Giuseppe, B., Deliliers, G.L., et al. (2010). Transplantation of undifferentiated human mesenchymal stem cells protects against 6-hydroxydopamine neurotoxicity in the rat. Cell Transplant 19, 203-217.

Borta, A., and Hoglinger, G.U. (2007). Dopamine and adult neurogenesis. J Neurochem $100,587-595$.

Bouchez, G., Sensebe, L., Vourc'h, P., Garreau, L., Bodard, S., Rico, A., Guilloteau, D., Charbord, P., Besnard, J.C., and Chalon, S. (2008). Partial recovery of dopaminergic pathway after graft of adult mesenchymal stem cells in a rat model of Parkinson's disease. Neurochem Int 52, 1332-1342.

Braak, H., Del Tredici, K., Bratzke, H., Hamm-Clement, J., Sandmann-Keil, D., and Rub, U. (2002). Staging of the intracerebral inclusion body pathology associated with idiopathic Parkinson's disease (preclinical and clinical stages). J Neurol 249 Suppl $3, \mathrm{III} / 1-5$.

Bradley, J.A., Bolton, E.M., and Pedersen, R.A. (2002). Stem cell medicine encounters the immune system. Nat Rev Immunol 2, 859-871.

Brederlau, A., Correia, A.S., Anisimov, S.V., Elmi, M., Paul, G., Roybon, L., Morizane, A., Bergquist, F., Riebe, I., Nannmark, U., et al. (2006). Transplantation of human embryonic stem cell-derived cells to a rat model of Parkinson's disease: effect of in 
vitro differentiation on graft survival and teratoma formation. Stem Cells 24,1433 1440.

Bronstein, J.M., Tagliati, M., Alterman, R.L., Lozano, A.M., Volkmann, J., Stefani, A., Horak, F.B., Okun, M.S., Foote, K.D., Krack, P., et al. (2011). Deep brain stimulation for Parkinson disease: an expert consensus and review of key issues. Arch Neurol 68, 165.

Cai, J., Yang, M., Poremsky, E., Kidd, S., Schneider, J.S., and Iacovitti, L. (2010). Dopaminergic neurons derived from human induced pluripotent stem cells survive and integrate into 6-OHDA-lesioned rats. Stem Cells Dev 19, 1017-1023.

Calvanese, V., Horrillo, A., Hmadcha, A., Suarez-Alvarez, B., Fernandez, A.F., Lara, E., Casado, S., Menendez, P., Bueno, C., Garcia-Castro, J., et al. (2008). Cancer genes hypermethylated in human embryonic stem cells. PLoS One 3, e3294.

Canet-Aviles, R.M., Wilson, M.A., Miller, D.W., Ahmad, R., McLendon, C., Bandyopadhyay, S., Baptista, M.J., Ringe, D., Petsko, G.A., and Cookson, M.R. (2004). The Parkinson's disease protein DJ-1 is neuroprotective due to cysteinesulfinic acid-driven mitochondrial localization. Proc Natl Acad Sci U S A 101, 9103-9108.

Carlsson, T., Carta, M., Munoz, A., Mattsson, B., Winkler, C., Kirik, D., and Bjorklund, A. (2009). Impact of grafted serotonin and dopamine neurons on development of LDOPA-induced dyskinesias in parkinsonian rats is determined by the extent of dopamine neuron degeneration. Brain 132, 319-335.

Carlsson, T., Carta, M., Winkler, C., Bjorklund, A., and Kirik, D. (2007). Serotonin neuron transplants exacerbate L-DOPA-induced dyskinesias in a rat model of Parkinson's disease. J Neurosci 27, 8011-8022.

Chaudhuri, K.R., Healy, D.G., and Schapira, A.H. (2006). Non-motor symptoms of Parkinson's disease: diagnosis and management. Lancet Neurol 5, 235-245.

Chen, L.W., Kuang, F., Wei, L.C., Ding, Y.X., Yung, K.K., and Chan, Y.S. (2011). Potential application of induced pluripotent stem cells in cell replacement therapy for Parkinson's disease. CNS Neurol Disord Drug Targets 10, 449-458.

Chin, M.H., Mason, M.J., Xie, W., Volinia, S., Singer, M., Peterson, C., Ambartsumyan, G., Aimiuwu, O., Richter, L., Zhang, J., et al. (2009). Induced pluripotent stem cells and embryonic stem cells are distinguished by gene expression signatures. Cell Stem Cell 5, 111-123.

Chiu, A.Y., and Hall, Z.W. (2006). Stem cell research: the California experience. J Neurosci 26, 6661-6663.

Cho, H.J., Lee, C.S., Kwon, Y.W., Paek, J.S., Lee, S.H., Hur, J., Lee, E.J., Roh, T.Y., Chu, I.S., Leem, S.H., et al. (2010). Induction of pluripotent stem cells from adult somatic cells by protein-based reprogramming without genetic manipulation. Blood 116, 386-395.

Christine, C.W., Starr, P.A., Larson, P.S., Eberling, J.L., Jagust, W.J., Hawkins, R.A., VanBrocklin, H.F., Wright, J.F., Bankiewicz, K.S., and Aminoff, M.J. (2009). Safety and tolerability of putaminal AADC gene therapy for Parkinson disease. Neurology 73, 1662-1669.

Chung, S., Shin, B.S., Hwang, M., Lardaro, T., Kang, U.J., Isacson, O., and Kim, K.S. (2006). Neural precursors derived from embryonic stem cells, but not those from 
fetal ventral mesencephalon, maintain the potential to differentiate into dopaminergic neurons after expansion in vitro. Stem Cells 24, 1583-1593.

Clarke, C.E., and Guttman, M. (2002). Dopamine agonist monotherapy in Parkinson's disease. Lancet 360, 1767-1769.

Cogle, C.R., Yachnis, A.T., Laywell, E.D., Zander, D.S., Wingard, J.R., Steindler, D.A., and Scott, E.W. (2004). Bone marrow transdifferentiation in brain after transplantation: a retrospective study. Lancet 363, 1432-1437.

Connor, B., and Dragunow, M. (1998). The role of neuronal growth factors in neurodegenerative disorders of the human brain. Brain Res Brain Res Rev 27, 1-39.

Cookson, M.R., Dauer, W., Dawson, T., Fon, E.A., Guo, M., and Shen, J. (2007). The roles of kinases in familial Parkinson's disease. J Neurosci 27, 11865-11868.

Corti, O., Lesage, S., and Brice, A. (2011). What Genetics Tells us About the Causes and Mechanisms of Parkinson's Disease. Physiological Reviews 91, 1161-1218

Creedon, D.J., Tansey, M.G., Baloh, R.H., Osborne, P.A., Lampe, P.A., Fahrner, T.J., Heuckeroth, R.O., Milbrandt, J., and Johnson, E.M., Jr. (1997). Neurturin shares receptors and signal transduction pathways with glial cell line-derived neurotrophic factor in sympathetic neurons. Proc Natl Acad Sci U S A 94, 7018-7023.

Croll, S.D., Suri, C., Compton, D.L., Simmons, M.V., Yancopoulos, G.D., Lindsay, R.M., Wiegand, S.J., Rudge, J.S., and Scharfman, H.E. (1999). Brain-derived neurotrophic factor transgenic mice exhibit passive avoidance deficits, increased seizure severity and in vitro hyperexcitability in the hippocampus and entorhinal cortex. Neuroscience 93, 1491-1506.

Davis, K.L., Edin, H.M., and Allen, J.K. (2010). Prevalence and cost of medication nonadherence in Parkinson's disease: evidence from administrative claims data. Mov Disord 25, 474-480.

Dawson, T.M., and Dawson, V.L. (2010). The role of parkin in familial and sporadic Parkinson's disease. Mov Disord 25 Suppl 1, S32-39.

de la Fuente-Fernandez, R., and Stoessl, A.J. (2002). The placebo effect in Parkinson's disease. Trends Neurosci 25, 302-306.

de Lau, L.M., and Breteler, M.M. (2006). Epidemiology of Parkinson's disease. Lancet Neurol 5, 525-535.

Deierborg, T., Soulet, D., Roybon, L., Hall, V., and Brundin, P. (2008). Emerging restorative treatments for Parkinson's disease. Prog Neurobiol 85, 407-432.

Diamond, S.G., Markham, C.H., and Treciokas, L.J. (1985). Double-blind trial of pergolide for Parkinson's disease. Neurology 35, 291-295.

Dimos, J.T., Rodolfa, K.T., Niakan, K.K., Weisenthal, L.M., Mitsumoto, H., Chung, W., Croft, G.F., Saphier, G., Leibel, R., Goland, R., et al. (2008). Induced pluripotent stem cells generated from patients with ALS can be differentiated into motor neurons. Science 321, 1218-1221.

Doi, A., Park, I.H., Wen, B., Murakami, P., Aryee, M.J., Irizarry, R., Herb, B., LaddAcosta, C., Rho, J., Loewer, S., et al. (2009). Differential methylation of tissueand cancer-specific $\mathrm{CpG}$ island shores distinguishes human induced pluripotent stem cells, embryonic stem cells and fibroblasts. Nat Genet 41, 1350-1353.

Drukker, M., Katz, G., Urbach, A., Schuldiner, M., Markel, G., Itskovitz-Eldor, J., Reubinoff, B., Mandelboim, O., and Benvenisty, N. (2002). Characterization of the 
expression of MHC proteins in human embryonic stem cells. Proc Natl Acad Sci U S A 99, 9864-9869.

Duan, W., Peng, Q., Masuda, N., Ford, E., Tryggestad, E., Ladenheim, B., Zhao, M., Cadet, J.L., Wong, J., and Ross, C.A. (2008). Sertraline slows disease progression and increases neurogenesis in N171-82Q mouse model of Huntington's disease. Neurobiol Dis 30, 312-322.

Emborg, M.E., Carbon, M., Holden, J.E., During, M.J., Ma, Y., Tang, C., Moirano, J., Fitzsimons, H., Roitberg, B.Z., Tuccar, E., et al. (2007). Subthalamic glutamic acid decarboxylase gene therapy: changes in motor function and cortical metabolism. J Cereb Blood Flow Metab 27, 501-509.

Ericson, C., Georgievska, B., and Lundberg, C. (2005). Ex vivo gene delivery of GDNF using primary astrocytes transduced with a lentiviral vector provides neuroprotection in a rat model of Parkinson's disease. Eur J Neurosci 22, 27552764.

Eriksson, P.S., Perfilieva, E., Bjork-Eriksson, T., Alborn, A.M., Nordborg, C., Peterson, D.A., and Gage, F.H. (1998). Neurogenesis in the adult human hippocampus. Nat Med 4, 1313-1317.

Eslamboli, A., Georgievska, B., Ridley, R.M., Baker, H.F., Muzyczka, N., Burger, C., Mandel, R.J., Annett, L., and Kirik, D. (2005). Continuous low-level glial cell linederived neurotrophic factor delivery using recombinant adeno-associated viral vectors provides neuroprotection and induces behavioral recovery in a primate model of Parkinson's disease. J Neurosci 25, 769-777.

Falk, T., Gonzalez, R.T., and Sherman, S.J. (2010). The Yin and Yang of VEGF and PEDF: Multifaceted Neurotrophic Factors and Their Potential in the Treatment of Parkinson's Disease. Int J Mol Sci 11, 2875-2900.

Feng, Q., Lu, S.J., Klimanskaya, I., Gomes, I., Kim, D., Chung, Y., Honig, G.R., Kim, K.S., and Lanza, R. (2010). Hemangioblastic derivatives from human induced pluripotent stem cells exhibit limited expansion and early senescence. Stem Cells 28, 704-712.

Fjord-Larsen, L., Johansen, J.L., Kusk, P., Tornoe, J., Gronborg, M., Rosenblad, C., and Wahlberg, L.U. (2005). Efficient in vivo protection of nigral dopaminergic neurons by lentiviral gene transfer of a modified Neurturin construct. Exp Neurol 195, 4960.

Freed, C.R., Greene, P.E., Breeze, R.E., Tsai, W.Y., DuMouchel, W., Kao, R., Dillon, S., Winfield, H., Culver, S., Trojanowski, J.Q., et al. (2001). Transplantation of embryonic dopamine neurons for severe Parkinson's disease. N Engl J Med 344, $710-719$.

Fukuda, H., and Takahashi, J. (2005). Embryonic stem cells as a cell source for treating Parkinson's disease. Expert Opin Biol Ther 5, 1273-1280.

Fukuda, H., Takahashi, J., Watanabe, K., Hayashi, H., Morizane, A., Koyanagi, M., Sasai, Y., and Hashimoto, N. (2006). Fluorescence-activated cell sorting-based purification of embryonic stem cell-derived neural precursors averts tumor formation after transplantation. Stem Cells 24, 763-771.

Funayama, M., Hasegawa, K., Kowa, H., Saito, M., Tsuji, S., and Obata, F. (2002). A new locus for Parkinson's disease (PARK8) maps to chromosome 12p11.2-q13.1. Ann Neurol 51, 296-301. 
Gash, D.M., Zhang, Z., Ovadia, A., Cass, W.A., Yi, A., Simmerman, L., Russell, D., Martin, D., Lapchak, P.A., Collins, F., et al. (1996). Functional recovery in parkinsonian monkeys treated with GDNF. Nature 380, 252-255.

Gasser, T. (2007). Update on the genetics of Parkinson's disease. Mov Disord 22 Suppl $17, \mathrm{~S} 343-350$.

Ghosh, Z., Huang, M., Hu, S., Wilson, K.D., Dey, D., and Wu, J.C. (2011). Dissecting the oncogenic and tumorigenic potential of differentiated human induced pluripotent stem cells and human embryonic stem cells. Cancer Res 71, 5030-5039.

Gill, S.S., Patel, N.K., Hotton, G.R., O'Sullivan, K., McCarter, R., Bunnage, M., Brooks, D.J., Svendsen, C.N., and Heywood, P. (2003). Direct brain infusion of glial cell line-derived neurotrophic factor in Parkinson disease. Nat Med 9, 589-595.

Glavaski-Joksimovic, A., Virag, T., Mangatu, T.A., McGrogan, M., Wang, X.S., and Bohn, M.C. (2010). Glial cell line-derived neurotrophic factor-secreting genetically modified human bone marrow-derived mesenchymal stem cells promote recovery in a rat model of Parkinson's disease. J Neurosci Res 88, 2669-2681.

Goedert, M., Spillantini, M.G., and Davies, S.W. (1998). Filamentous nerve cell inclusions in neurodegenerative diseases. Curr Opin Neurobiol 8, 619-632.

Goetz, C.G., Leurgans, S., Raman, R., and Stebbins, G.T. (2000). Objective changes in motor function during placebo treatment in PD. Neurology 54, 710-714.

Goetz, C.G., Stebbins, G.T., 3rd, Klawans, H.L., Koller, W.C., Grossman, R.G., Bakay, R.A., and Penn, R.D. (1991). United Parkinson Foundation Neurotransplantation Registry on adrenal medullary transplants: presurgical, and 1- and 2-year followup. Neurology 41, 1719-1722.

Goetz, C.G., Tilley, B.C., Shaftman, S.R., Stebbins, G.T., Fahn, S., Martinez-Martin, P., Poewe, W., Sampaio, C., Stern, M.B., Dodel, R., et al. (2008). Movement Disorder Society-sponsored revision of the Unified Parkinson's Disease Rating Scale (MDSUPDRS): scale presentation and clinimetric testing results. Mov Disord 23, 21292170.

Goldberg, M.S., and Lansbury, P.T. (2000). Is there a cause-and-effect relationship between alpha-synuclein fibrillization and Parkinson's disease? Nat Cell Biol 2, E115-E119.

Golestaneh, N., Kokkinaki, M., Pant, D., Jiang, J., DeStefano, D., Fernandez-Bueno, C., Rone, J.D., Haddad, B.R., Gallicano, G.I., and Dym, M. (2009). Pluripotent stem cells derived from adult human testes. Stem Cells Dev 18, 1115-1126.

Gottweis, H., and Minger, S. (2008). iPS cells and the politics of promise. Nat Biotechnol 26, 271-272.

Grondin, R., Zhang, Z., Ai, Y., Ding, F., Walton, A.A., Surgener, S.P., Gerhardt, G.A., and Gash, D.M. (2008). Intraputamenal infusion of exogenous neurturin protein restores motor and dopaminergic function in the globus pallidus of MPTP-lesioned rhesus monkeys. Cell Transplant 17, 373-381.

Gu, S., Huang, H., Bi, J., Yao, Y., and Wen, T. (2009). Combined treatment of neurotrophin-3 gene and neural stem cells is ameliorative to behavior recovery of Parkinson's disease rat model. Brain Res 1257, 1-9.

Gutierrez-Aranda, I., Ramos-Mejia, V., Bueno, C., Munoz-Lopez, M., Real, P.J., Macia, A., Sanchez, L., Ligero, G., Garcia-Parez, J.L., and Menendez, P. (2010). Human induced pluripotent stem cells develop teratoma more efficiently and faster than 
human embryonic stem cells regardless the site of injection. Stem Cells $28,1568-$ 1570.

Hagell, P., and Brundin, P. (2001). Cell survival and clinical outcome following intrastriatal transplantation in Parkinson disease. J Neuropathol Exp Neurol 60, 741-752.

Hagell, P., Schrag, A., Piccini, P., Jahanshahi, M., Brown, R., Rehncrona, S., Widner, H., Brundin, P., Rothwell, J.C., Odin, P., et al. (1999). Sequential bilateral transplantation in Parkinson's disease: effects of the second graft. Brain 122 ( Pt 6), $1121-1132$.

Hagg, T. (2009). From neurotransmitters to neurotrophic factors to neurogenesis. Neuroscientist 15, 20-27.

Halliday, G.M., and McCann, H. (2010). The progression of pathology in Parkinson's disease. Ann N Y Acad Sci 1184, 188-195.

Hammond, C., Bergman, H., and Brown, P. (2007). Pathological synchronization in Parkinson's disease: networks, models and treatments. Trends Neurosci 30, 357364.

Hargus, G., Cooper, O., Deleidi, M., Levy, A., Lee, K., Marlow, E., Yow, A., Soldner, F., Hockemeyer, D., Hallett, P.J., et al. (2010). Differentiated Parkinson patientderived induced pluripotent stem cells grow in the adult rodent brain and reduce motor asymmetry in Parkinsonian rats. Proc Natl Acad Sci U S A 107, 1592115926.

Harrison, N.J., Baker, D., and Andrews, P.W. (2007). Culture adaptation of embryonic stem cells echoes germ cell malignancy. Int J Androl 30, 275-281; discussion 281.

Hatano, T., Kubo, S., Sato, S., and Hattori, N. (2009). Pathogenesis of familial Parkinson's disease: new insights based on monogenic forms of Parkinson's disease. J Neurochem 111, 1075-1093.

Hauser, R.A., Freeman, T.B., Snow, B.J., Nauert, M., Gauger, L., Kordower, J.H., and Olanow, C.W. (1999). Long-term evaluation of bilateral fetal nigral transplantation in Parkinson disease. Arch Neurol 56, 179-187.

Hedlund, E., Pruszak, J., Lardaro, T., Ludwig, W., Vinuela, A., Kim, K.S., and Isacson, O. (2008). Embryonic stem cell-derived Pitx3-enhanced green fluorescent protein midbrain dopamine neurons survive enrichment by fluorescence-activated cell sorting and function in an animal model of Parkinson's disease. Stem Cells 26, 1526-1536.

Hiyama, E., and Hiyama, K. (2007). Telomere and telomerase in stem cells. Br J Cancer 96, 1020-1024.

Hochedlinger, K., and Plath, K. (2009). Epigenetic reprogramming and induced pluripotency. Development 136, 509-523.

Horger, B.A., Nishimura, M.C., Armanini, M.P., Wang, L.C., Poulsen, K.T., Rosenblad, C., Kirik, D., Moffat, B., Simmons, L., Johnson, E., Jr., et al. (1998). Neurturin exerts potent actions on survival and function of midbrain dopaminergic neurons. $J$ Neurosci 18, 4929-4937.

Huangfu, D., Osafune, K., Maehr, R., Guo, W., Eijkelenboom, A., Chen, S., Muhlestein, W., and Melton, D.A. (2008). Induction of pluripotent stem cells from primary human fibroblasts with only Oct4 and Sox2. Nat Biotechnol 26, 1269-1275. 
Jarraya, B., Boulet, S., Ralph, G.S., Jan, C., Bonvento, G., Azzouz, M., Miskin, J.E., Shin, M., Delzescaux, T., Drouot, X., et al. (2009). Dopamine gene therapy for Parkinson's disease in a nonhuman primate without associated dyskinesia. Sci Transl Med 1, 2ra4.

Jia, F., Wilson, K.D., Sun, N., Gupta, D.M., Huang, M., Li, Z., Panetta, N.J., Chen, Z.Y., Robbins, R.C., Kay, M.A., et al. (2010). A nonviral minicircle vector for deriving human iPS cells. Nat Methods 7, 197-199.

Jin, G.Z., Cho, S.J., Choi, E.G., Lee, Y.S., Yu, X.F., Choi, K.S., Yee, S.T., Jeon, J.T., Kim, M.O., and Kong, I.K. (2008). Rat mesenchymal stem cells increase tyrosine hydroxylase expression and dopamine content in ventral mesencephalic cells in vitro. Cell Biol Int 32, 1433-1438.

Jonsson, M.E., Ono, Y., Bjorklund, A., and Thompson, L.H. (2009). Identification of transplantable dopamine neuron precursors at different stages of midbrain neurogenesis. Experimental Neurology 219, 341-354.

Kang, U.J., Lee, W.Y., and Chang, J.W. (2001). Gene therapy for Parkinson's disease: determining the genes necessary for optimal dopamine replacement in rat models. Hum Cell 14, 39-48.

Kaplitt, M.G., Feigin, A., Tang, C., Fitzsimons, H.L., Mattis, P., Lawlor, P.A., Bland, R.J., Young, D., Strybing, K., Eidelberg, D., et al. (2007). Safety and tolerability of gene therapy with an adeno-associated virus (AAV) borne GAD gene for Parkinson's disease: an open label, phase I trial. Lancet 369, 2097-2105.

Katsnelson, A. (2011). Experimental therapies for Parkinson's disease: Why fake it? Nature 476, 142-144.

Katzenschlager, R., Sampaio, C., Costa, J., and Lees, A. (2003). Anticholinergics for symptomatic management of Parkinson's disease. Cochrane Database Syst Rev, CD003735.

Kawasaki, H., Mizuseki, K., Nishikawa, S., Kaneko, S., Kuwana, Y., Nakanishi, S., Nishikawa, S.I., and Sasai, Y. (2000). Induction of midbrain dopaminergic neurons from ES cells by stromal cell-derived inducing activity. Neuron 28, 31-40.

Kim, D.W., Chung, S., Hwang, M., Ferree, A., Tsai, H.C., Park, J.J., Nam, T.S., Kang, U.J., Isacson, O., and Kim, K.S. (2006). Stromal cell-derived inducing activity, Nurr1, and signaling molecules synergistically induce dopaminergic neurons from mouse embryonic stem cells. Stem Cells 24, 557-567.

Kim, E.Y., Jeon, K., Park, H.Y., Han, Y.J., Yang, B.C., Park, S.B., Chung, H.M., and Park, S.P. (2010). Differences between cellular and molecular profiles of induced pluripotent stem cells generated from mouse embryonic fibroblasts. Cell Reprogram 12, 627-639.

Kim, J.H., Auerbach, J.M., Rodriguez-Gomez, J.A., Velasco, I., Gavin, D., Lumelsky, N., Lee, S.H., Nguyen, J., Sanchez-Pernaute, R., Bankiewicz, K., et al. (2002). Dopamine neurons derived from embryonic stem cells function in an animal model of Parkinson's disease. Nature 418, 50-56.

Klein, R.L., Lewis, M.H., Muzyczka, N., and Meyer, E.M. (1999). Prevention of 6hydroxydopamine-induced rotational behavior by BDNF somatic gene transfer. Brain Res 847, 314-320. 
Kordower, J.H., Chu, Y., Hauser, R.A., Freeman, T.B., and Olanow, C.W. (2008). Lewy body-like pathology in long-term embryonic nigral transplants in Parkinson's disease. Nat Med 14, 504-506.

Kordower, J.H., Herzog, C.D., Dass, B., Bakay, R.A., Stansell, J., 3rd, Gasmi, M., and Bartus, R.T. (2006). Delivery of neurturin by AAV2 (CERE-120)-mediated gene transfer provides structural and functional neuroprotection and neurorestoration in MPTP-treated monkeys. Ann Neurol 60, 706-715.

Kotzbauer, P.T., Lampe, P.A., Heuckeroth, R.O., Golden, J.P., Creedon, D.J., Johnson, E.M., Jr., and Milbrandt, J. (1996). Neurturin, a relative of glial-cell-line-derived neurotrophic factor. Nature 384, 467-470.

Kriks, S., Shim, J.W., Piao, J., Ganat, Y.M., Wakeman, D.R., Xie, Z., Carrillo-Reid, L., Auyeung, G., Antonacci, C., Buch, A., et al. (2011). Dopamine neurons derived from human ES cells efficiently engraft in animal models of Parkinson's disease. Nature.

Kunisato, A., Wakatsuki, M., Kodama, Y., Shinba, H., Ishida, I., and Nagao, K. (2010). Generation of induced pluripotent stem cells by efficient reprogramming of adult bone marrow cells. Stem Cells Dev 19, 229-238.

Lane, E.L., Bjorklund, A., Dunnett, S.B., and Winkler, C. (2010). Neural grafting in Parkinson's disease unraveling the mechanisms underlying graft-induced dyskinesia. Prog Brain Res 184, 295-309.

Lang, A.E., Gill, S., Patel, N.K., Lozano, A., Nutt, J.G., Penn, R., Brooks, D.J., Hotton, G., Moro, E., Heywood, P., et al. (2006). Randomized controlled trial of intraputamenal glial cell line-derived neurotrophic factor infusion in Parkinson disease. Ann Neurol 59, 459-466.

Lansbury, P.T., Conway, K.A., Rochet, J.C., and Bieganski, R.M. (2001). Kinetic stabilization of the alpha-synuclein protofibril by a dopamine-alpha-synuclein adduct. Science 294, 1346-1349.

Larsen, C.N., Krantz, B.A., and Wilkinson, K.D. (1998). Substrate specificity of deubiquitinating enzymes: ubiquitin C-terminal hydrolases. Biochemistry 37,3358 3368.

Lee, B., Lee, H., Nam, Y.R., Oh, J.H., Cho, Y.H., and Chang, J.W. (2005). Enhanced expression of glutamate decarboxylase 65 improves symptoms of rat parkinsonian models. Gene Ther 12, 1215-1222.

Lee, S.H., Lumelsky, N., Studer, L., Auerbach, J.M., and McKay, R.D. (2000). Efficient generation of midbrain and hindbrain neurons from mouse embryonic stem cells. Nat Biotechnol 18,675-679.

Lei, T., Jacob, S., Ajil-Zaraa, I., Dubuisson, J.B., Irion, O., Jaconi, M., and Feki, A. (2007). Xeno-free derivation and culture of human embryonic stem cells: current status, problems and challenges. Cell Res 17, 682-688.

Lesage, S., and Brice, A. (2009). Parkinson's disease: from monogenic forms to genetic susceptibility factors. Hum Mol Genet 18, R48-59.

Levine, R.A., Miller, L.P., and Lovenberg, W. (1981). Tetrahydrobiopterin in striatum: localization in dopamine nerve terminals and role in catecholamine synthesis. Science 214, 919-921.

Levivier, M., Przedborski, S., Bencsics, C., and Kang, U.J. (1995). Intrastriatal implantation of fibroblasts genetically engineered to produce brain-derived 
neurotrophic factor prevents degeneration of dopaminergic neurons in a rat model of Parkinson's disease. J Neurosci 15, 7810-7820.

LeWitt, P.A., Rezai, A.R., Leehey, M.A., Ojemann, S.G., Flaherty, A.W., Eskandar, E.N., Kostyk, S.K., Thomas, K., Sarkar, A., Siddiqui, M.S., et al. (2011). AAV2GAD gene therapy for advanced Parkinson's disease: a double-blind, sham-surgery controlled, randomised trial. Lancet Neurol 10, 309-319.

Li, J.Y., Englund, E., Holton, J.L., Soulet, D., Hagell, P., Lees, A.J., Lashley, T., Quinn, N.P., Rehncrona, S., Bjorklund, A., et al. (2008). Lewy bodies in grafted neurons in subjects with Parkinson's disease suggest host-to-graft disease propagation. Nat Med 14, 501-503.

Li, W., Hoffman, P.N., Stirling, W., Price, D.L., and Lee, M.K. (2004). Axonal transport of human alpha-synuclein slows with aging but is not affected by familial Parkinson's disease-linked mutations. J Neurochem 88, 401-410.

Li, X.G., Okada, T., Kodera, M., Nara, Y., Takino, N., Muramatsu, C., Ikeguchi, K., Urano, F., Ichinose, H., Metzger, D., et al. (2006). Viral-mediated temporally controlled dopamine production in a rat model of Parkinson disease. Mol Ther 13, 160-166.

Li, Y., Chen, J., Wang, L., Zhang, L., Lu, M., and Chopp, M. (2001). Intracerebral transplantation of bone marrow stromal cells in a 1-methyl-4-phenyl-1,2,3,6tetrahydropyridine mouse model of Parkinson's disease. Neurosci Lett 316, 67-70.

Lie, D.C., Dziewczapolski, G., Willhoite, A.R., Kaspar, B.K., Shults, C.W., and Gage, F.H. (2002). The adult substantia nigra contains progenitor cells with neurogenic potential. J Neurosci 22, 6639-6649.

Limousin, P., Krack, P., Pollak, P., Benazzouz, A., Ardouin, C., Hoffmann, D., and Benabid, A.L. (1998). Electrical stimulation of the subthalamic nucleus in advanced Parkinson's disease. N Engl J Med 339, 1105-1111.

Lin, L.F., Doherty, D.H., Lile, J.D., Bektesh, S., and Collins, F. (1993). GDNF: a glial cell line-derived neurotrophic factor for midbrain dopaminergic neurons. Science 260, 1130-1132.

Lindholm, P., Voutilainen, M.H., Lauren, J., Peranen, J., Leppanen, V.M., Andressoo, J.O., Lindahl, M., Janhunen, S., Kalkkinen, N., Timmusk, T., et al. (2007). Novel neurotrophic factor CDNF protects and rescues midbrain dopamine neurons in vivo. Nature 448, 73-77.

Lindvall, O., Brundin, P., Widner, H., Rehncrona, S., Gustavii, B., Frackowiak, R., Leenders, K.L., Sawle, G., Rothwell, J.C., Marsden, C.D., et al. (1990). Grafts of fetal dopamine neurons survive and improve motor function in Parkinson's disease. Science 247, 574-577.

Litvan, I., Chesselet, M.F., Gasser, T., Di Monte, D.A., Parker, D., Jr., Hagg, T., Hardy, J., Jenner, P., Myers, R.H., Price, D., et al. (2007a). The etiopathogenesis of Parkinson disease and suggestions for future research. Part II. J Neuropathol Exp Neurol 66, 329-336.

Litvan, I., Halliday, G., Hallett, M., Goetz, C.G., Rocca, W., Duyckaerts, C., BenShlomo, Y., Dickson, D.W., Lang, A.E., Chesselet, M.F., et al. (2007b). The etiopathogenesis of Parkinson disease and suggestions for future research. Part I. J Neuropathol Exp Neurol 66, 251-257. 
Liu, W.G., Lu, G.Q., Li, B., and Chen, S.D. (2007). Dopaminergic neuroprotection by neurturin-expressing c17.2 neural stem cells in a rat model of Parkinson's disease. Parkinsonism Relat Disord 13,77-88.

Lowe, J., McDermott, H., Landon, M., Mayer, R.J., and Wilkinson, K.D. (1990). Ubiquitin carboxyl-terminal hydrolase (PGP 9.5) is selectively present in ubiquitinated inclusion bodies characteristic of human neurodegenerative diseases. J Pathol 161, 153-160.

Lu, P., Jones, L.L., Snyder, E.Y., and Tuszynski, M.H. (2003). Neural stem cells constitutively secrete neurotrophic factors and promote extensive host axonal growth after spinal cord injury. Exp Neurol 181, 115-129.

Lundberg, C., Bjorklund, T., Carlsson, T., Jakobsson, J., Hantraye, P., Deglon, N., and Kirik, D. (2008). Applications of lentiviral vectors for biology and gene therapy of neurological disorders. Curr Gene Ther 8, 461-473.

Lykissas, M.G., Batistatou, A.K., Charalabopoulos, K.A., and Beris, A.E. (2007). The role of neurotrophins in axonal growth, guidance, and regeneration. Curr Neurovasc Res 4, 143-151.

Madrazo, I., Drucker-Colin, R., Diaz, V., Martinez-Mata, J., Torres, C., and Becerril, J.J. (1987). Open microsurgical autograft of adrenal medulla to the right caudate nucleus in two patients with intractable Parkinson's disease. N Engl J Med 316, 831-834.

Mallanna, S.K., and Rizzino, A. (2010). Emerging roles of microRNAs in the control of embryonic stem cells and the generation of induced pluripotent stem cells. Dev Biol 344, 16-25.

Mallon, B.S., Park, K.Y., Chen, K.G., Hamilton, R.S., and McKay, R.D. (2006). Toward xeno-free culture of human embryonic stem cells. Int J Biochem Cell Biol 38, 1063-1075.

Mandel, R.J., Spratt, S.K., Snyder, R.O., and Leff, S.E. (1997). Midbrain injection of recombinant adeno-associated virus encoding rat glial cell line-derived neurotrophic factor protects nigral neurons in a progressive 6-hydroxydopamineinduced degeneration model of Parkinson's disease in rats. Proc Natl Acad Sci U S A $94,14083-14088$.

Marks, W.J., Jr., Bartus, R.T., Siffert, J., Davis, C.S., Lozano, A., Boulis, N., Vitek, J., Stacy, M., Turner, D., Verhagen, L., et al. (2010). Gene delivery of AAV2neurturin for Parkinson's disease: a double-blind, randomised, controlled trial. Lancet Neurol 9, 1164-1172.

Marks, W.J., Jr., Ostrem, J.L., Verhagen, L., Starr, P.A., Larson, P.S., Bakay, R.A., Taylor, R., Cahn-Weiner, D.A., Stoessl, A.J., Olanow, C.W., et al. (2008). Safety and tolerability of intraputaminal delivery of CERE-120 (adeno-associated virus serotype 2-neurturin) to patients with idiopathic Parkinson's disease: an open-label, phase I trial. Lancet Neurol 7, 400-408.

Martin, I., Dawson, V.L., and Dawson, T.M. (2011). Recent advances in the genetics of Parkinson's disease. Annu Rev Genomics Hum Genet 12, 301-325.

McLaren, F.H., Svendsen, C.N., Van der Meide, P., and Joly, E. (2001). Analysis of neural stem cells by flow cytometry: cellular differentiation modifies patterns of MHC expression. J Neuroimmunol 112, 35-46. 
McNaught, K.S., Belizaire, R., Isacson, O., Jenner, P., and Olanow, C.W. (2003). Altered proteasomal function in sporadic Parkinson's disease. Exp Neurol 179, 38-46.

Mendez, I., Sanchez-Pernaute, R., Cooper, O., Vinuela, A., Ferrari, D., Bjorklund, L., Dagher, A., and Isacson, O. (2005). Cell type analysis of functional fetal dopamine cell suspension transplants in the striatum and substantia nigra of patients with Parkinson's disease. Brain 128, 1498-1510.

Mendez, I., Vinuela, A., Astradsson, A., Mukhida, K., Hallett, P., Robertson, H., Tierney, T., Holness, R., Dagher, A., Trojanowski, J.Q., et al. (2008). Dopamine neurons implanted into people with Parkinson's disease survive without pathology for 14 years. Nat Med 14, 507-509.

Mestre, T., and Ferreira, J.J. (2010). Pharmacotherapy in Parkinson's disease: case studies. Ther Adv Neurol Disord 3, 117-126.

Morandi, F., Raffaghello, L., Bianchi, G., Meloni, F., Salis, A., Millo, E., Ferrone, S., Barnaba, V., and Pistoia, V. (2008). Immunogenicity of human mesenchymal stem cells in HLA-class I-restricted T-cell responses against viral or tumor-associated antigens. Stem Cells 26, 1275-1287.

Morizane, A., Li, J.Y., and Brundin, P. (2008). From bench to bed: the potential of stem cells for the treatment of Parkinson's disease. Cell Tissue Res 331, 323-336.

Muramatsu, S., Fujimoto, K., Ikeguchi, K., Shizuma, N., Kawasaki, K., Ono, F., Shen, Y., Wang, L., Mizukami, H., Kume, A., et al. (2002). Behavioral recovery in a primate model of Parkinson's disease by triple transduction of striatal cells with adeno-associated viral vectors expressing dopamine-synthesizing enzymes. Hum Gene Ther 13, 345-354.

Muramatsu, S., Fujimoto, K., Kato, S., Mizukami, H., Asari, S., Ikeguchi, K., Kawakami, T., Urabe, M., Kume, A., Sato, T., et al. (2010). A phase I study of aromatic Lamino acid decarboxylase gene therapy for Parkinson's disease. Mol Ther 18, 17311735.

Muramatsu, S., Okuno, T., Suzuki, Y., Nakayama, T., Kakiuchi, T., Takino, N., Iida, A., Ono, F., Terao, K., Inoue, N., et al. (2009). Multitracer assessment of dopamine function after transplantation of embryonic stem cell-derived neural stem cells in a primate model of Parkinson's disease. Synapse 63, 541-548.

Nakagawa, M., Koyanagi, M., Tanabe, K., Takahashi, K., Ichisaka, T., Aoi, T., Okita, K., Mochiduki, Y., Takizawa, N., and Yamanaka, S. (2008). Generation of induced pluripotent stem cells without Myc from mouse and human fibroblasts. Nat Biotechnol 26, 101-106.

Newman, M.B., and Bakay, R.A. (2008). Therapeutic potentials of human embryonic stem cells in Parkinson's disease. Neurotherapeutics 5, 237-251.

Nishikawa, S., Goldstein, R.A., and Nierras, C.R. (2008). The promise of human induced pluripotent stem cells for research and therapy. Nat Rev Mol Cell Biol 9, 725-729.

Nutt, J.G., Burchiel, K.J., Comella, C.L., Jankovic, J., Lang, A.E., Laws, E.R., Jr., Lozano, A.M., Penn, R.D., Simpson, R.K., Jr., Stacy, M., et al. (2003). Randomized, double-blind trial of glial cell line-derived neurotrophic factor (GDNF) in PD. Neurology 60, 69-73.

O'Keeffe, F.E., Scott, S.A., Tyers, P., O'Keeffe, G.W., Dalley, J.W., Zufferey, R., and Caldwell, M.A. (2008). Induction of A9 dopaminergic neurons from neural stem 
cells improves motor function in an animal model of Parkinson's disease. Brain $131,630-641$.

Ohm, J.E., Mali, P., Van Neste, L., Berman, D.M., Liang, L., Pandiyan, K., Briggs, K.J., Zhang, W., Argani, P., Simons, B., et al. (2010). Cancer-related epigenome changes associated with reprogramming to induced pluripotent stem cells. Cancer Res 70, 7662-7673.

Oiwa, Y., Yoshimura, R., Nakai, K., and Itakura, T. (2002). Dopaminergic neuroprotection and regeneration by neurturin assessed by using behavioral, biochemical and histochemical measurements in a model of progressive Parkinson's disease. Brain Res 947, 271-283.

Okita, K., Nakagawa, M., Hyenjong, H., Ichisaka, T., and Yamanaka, S. (2008). Generation of mouse induced pluripotent stem cells without viral vectors. Science 322, 949-953.

Olanow, C.W., Goetz, C.G., Kordower, J.H., Stoessl, A.J., Sossi, V., Brin, M.F., Shannon, K.M., Nauert, G.M., Perl, D.P., Godbold, J., et al. (2003). A double-blind controlled trial of bilateral fetal nigral transplantation in Parkinson's disease. Ann Neurol 54, 403-414.

Olanow, C.W., Obeso, J.A., and Stocchi, F. (2006). Drug insight: Continuous dopaminergic stimulation in the treatment of Parkinson's disease. Nat Clin Pract Neurol 2, 382-392.

Ostenfeld, T., Caldwell, M.A., Prowse, K.R., Linskens, M.H., Jauniaux, E., and Svendsen, C.N. (2000). Human neural precursor cells express low levels of telomerase in vitro and show diminishing cell proliferation with extensive axonal outgrowth following transplantation. Exp Neurol 164, 215-226.

Ostenfeld, T., Tai, Y.T., Martin, P., Deglon, N., Aebischer, P., and Svendsen, C.N. (2002). Neurospheres modified to produce glial cell line-derived neurotrophic factor increase the survival of transplanted dopamine neurons. J Neurosci Res 69 , 955-965.

Parish, C.L., Parisi, S., Persico, M.G., Arenas, E., and Minchiotti, G. (2005). Cripto as a target for improving embryonic stem cell-based therapy in Parkinson's disease. Stem Cells 23, 471-476.

Park, C.H., Minn, Y.K., Lee, J.Y., Choi, D.H., Chang, M.Y., Shim, J.W., Ko, J.Y., Koh, H.C., Kang, M.J., Kang, J.S., et al. (2005). In vitro and in vivo analyses of human embryonic stem cell-derived dopamine neurons. J Neurochem 92, 1265-1276.

Park, H.J., Lee, P.H., Bang, O.Y., Lee, G., and Ahn, Y.H. (2008a). Mesenchymal stem cells therapy exerts neuroprotection in a progressive animal model of Parkinson's disease. J Neurochem 107, 141-151.

Park, I.H., Arora, N., Huo, H., Maherali, N., Ahfeldt, T., Shimamura, A., Lensch, M.W., Cowan, C., Hochedlinger, K., and Daley, G.Q. (2008b). Disease-specific induced pluripotent stem cells. Cell 134, 877-886.

Parkkinen, L., Pirttila, T., Tervahauta, M., and Alafuzoff, I. (2005). Widespread and abundant alpha-synuclein pathology in a neurologically unimpaired subject. Neuropathology 25, 304-314.

Pereira, M.C., Secco, M., Suzuki, D.E., Janjoppi, L., Rodini, C.O., Torres, L.B., Araujo, B.H., Cavalheiro, E.A., Zatz, M., and Okamoto, O.K. (2011). Contamination of 
Mesenchymal Stem-Cells with Fibroblasts Accelerates Neurodegeneration in an Experimental Model of Parkinson's Disease. Stem Cell Rev.

Perrier, A.L., Tabar, V., Barberi, T., Rubio, M.E., Bruses, J., Topf, N., Harrison, N.L., and Studer, L. (2004). Derivation of midbrain dopamine neurons from human embryonic stem cells. Proc Natl Acad Sci U S A 101, 12543-12548.

Phinney, D.G., and Isakova, I. (2005). Plasticity and therapeutic potential of mesenchymal stem cells in the nervous system. Curr Pharm Des 11, 1255-1265.

Pittenger, M.F., Mackay, A.M., Beck, S.C., Jaiswal, R.K., Douglas, R., Mosca, J.D., Moorman, M.A., Simonetti, D.W., Craig, S., and Marshak, D.R. (1999). Multilineage potential of adult human mesenchymal stem cells. Science 284, 143147.

Politis, M., Wu, K., Loane, C., Quinn, N.P., Brooks, D.J., Rehncrona, S., Bjorklund, A., Lindvall, O., and Piccini, P. (2010). Serotonergic neurons mediate dyskinesia side effects in Parkinson's patients with neural transplants. Sci Transl Med 2, 38ra46.

Poston, K.L., and Waters, C. (2007). Zydis selegiline in the management of Parkinson's disease. Expert Opin Pharmacother 8, 2615-2624.

Preynat-Seauve, O., Burkhard, P.R., Villard, J., Zingg, W., Ginovart, N., Feki, A., Dubois-Dauphin, M., Hurst, S.A., Mauron, A., Jaconi, M., et al. (2009). Pluripotent stem cells as new drugs? The example of Parkinson's disease. Int J Pharm 381, 113 121.

Priller, J., Persons, D.A., Klett, F.F., Kempermann, G., Kreutzberg, G.W., and Dirnagl, U. (2001). Neogenesis of cerebellar Purkinje neurons from gene-marked bone marrow cells in vivo. J Cell Biol 155, 733-738.

Przedborski, S., Levivier, M., Jiang, H., Ferreira, M., Jackson-Lewis, V., Donaldson, D., and Togasaki, D.M. (1995). Dose-dependent lesions of the dopaminergic nigrostriatal pathway induced by intrastriatal injection of 6-hydroxydopamine. Neuroscience 67, 631-647.

Rangasamy, S.B., Soderstrom, K., Bakay, R.A., and Kordower, J.H. (2010). Neurotrophic factor therapy for Parkinson's disease. Prog Brain Res 184, 237-264.

Redmond, D.E., Jr., Bjugstad, K.B., Teng, Y.D., Ourednik, V., Ourednik, J., Wakeman, D.R., Parsons, X.H., Gonzalez, R., Blanchard, B.C., Kim, S.U., et al. (2007). Behavioral improvement in a primate Parkinson's model is associated with multiple homeostatic effects of human neural stem cells. Proc Natl Acad Sci U S A 104, 12175-12180.

Rizk, P., Salazar, J., Raisman-Vozari, R., Marien, M., Ruberg, M., Colpaert, F., and Debeir, T. (2006). The alpha2-adrenoceptor antagonist dexefaroxan enhances hippocampal neurogenesis by increasing the survival and differentiation of new granule cells. Neuropsychopharmacology 31, 1146-1157.

Rodriguez-Gomez, J.A., Lu, J.Q., Velasco, I., Rivera, S., Zoghbi, S.S., Liow, J.S., Musachio, J.L., Chin, F.T., Toyama, H., Seidel, J., et al. (2007). Persistent dopamine functions of neurons derived from embryonic stem cells in a rodent model of Parkinson disease. Stem Cells 25, 918-928.

Roy, N.S., Cleren, C., Singh, S.K., Yang, L., Beal, M.F., and Goldman, S.A. (2006). Functional engraftment of human ES cell-derived dopaminergic neurons enriched by coculture with telomerase-immortalized midbrain astrocytes. Nat Med 12, 12591268. 
Roy, N.S., Wang, S., Jiang, L., Kang, J., Benraiss, A., Harrison-Restelli, C., Fraser, R.A., Couldwell, W.T., Kawaguchi, A., Okano, H., et al. (2000). In vitro neurogenesis by progenitor cells isolated from the adult human hippocampus. Nat Med 6, 271-277.

Sadan, O., Bahat-Stromza, M., Barhum, Y., Levy, Y.S., Pisnevsky, A., Peretz, H., Ilan, A.B., Bulvik, S., Shemesh, N., Krepel, D., et al. (2009). Protective effects of neurotrophic factor-secreting cells in a 6-OHDA rat model of Parkinson disease. Stem Cells Dev 18, 1179-1190.

Sanchez-Pernaute, R., Lee, H., Patterson, M., Reske-Nielsen, C., Yoshizaki, T., Sonntag, K.C., Studer, L., and Isacson, O. (2008). Parthenogenetic dopamine neurons from primate embryonic stem cells restore function in experimental Parkinson's disease. Brain 131, 2127-2139.

Sanchez-Ramos, J., Song, S., Cardozo-Pelaez, F., Hazzi, C., Stedeford, T., Willing, A., Freeman, T.B., Saporta, S., Janssen, W., Patel, N., et al. (2000). Adult bone marrow stromal cells differentiate into neural cells in vitro. Exp Neurol 164, 247256.

Sariola, H., and Saarma, M. (2003). Novel functions and signalling pathways for GDNF. J Cell Sci 116, 3855-3862.

Sasaki, M., Radtke, C., Tan, A.M., Zhao, P., Hamada, H., Houkin, K., Honmou, O., and Kocsis, J.D. (2009). BDNF-hypersecreting human mesenchymal stem cells promote functional recovery, axonal sprouting, and protection of corticospinal neurons after spinal cord injury. J Neurosci 29, 14932-14941.

Schulz, J.B. (2008). Update on the pathogenesis of Parkinson's disease. J Neurol 255 Suppl 5, 3-7.

Schulz, T.C., Noggle, S.A., Palmarini, G.M., Weiler, D.A., Lyons, I.G., Pensa, K.A., Meedeniya, A.C., Davidson, B.P., Lambert, N.A., and Condie, B.G. (2004). Differentiation of human embryonic stem cells to dopaminergic neurons in serumfree suspension culture. Stem Cells 22, 1218-1238.

Secco, M., Moreira, Y.B., Zucconi, E., Vieira, N.M., Jazedje, T., Muotri, A.R., Okamoto, O.K., Verjovski-Almeida, S., and Zatz, M. (2009). Gene expression profile of mesenchymal stem cells from paired umbilical cord units: cord is different from blood. Stem Cell Rev 5, 387-401.

Sethi, K.D., Hauser, R.A., Isaacson, S.H., and McClain, T. (2009). Levodopa/carbidopa/entacapone 200/50/200 mg (Stalevo 200) in the treatment of Parkinson's disease: a case series. Cases J 2, 7134.

Shen, L.H., Li, Y., Chen, J., Zhang, J., Vanguri, P., Borneman, J., and Chopp, M. (2006). Intracarotid transplantation of bone marrow stromal cells increases axon-myelin remodeling after stroke. Neuroscience 137, 393-399.

Shetty, N., Friedman, J.H., Kieburtz, K., Marshall, F.J., and Oakes, D. (1999). The placebo response in Parkinson's disease. Parkinson Study Group. Clin Neuropharmacol 22, 207-212.

Shi, D., Chen, G., Lv, L., Li, L., Wei, D., Gu, P., Gao, J., Miao, Y., and Hu, W. (2011). The effect of lentivirus-mediated TH and GDNF genetic engineering mesenchymal stem cells on Parkinson's disease rat model. Neurol Sci 32, 41-51.

Shimura, H., Hattori, N., Kubo, S., Mizuno, Y., Asakawa, S., Minoshima, S., Shimizu, N., Iwai, K., Chiba, T., Tanaka, K., et al. (2000). Familial Parkinson disease gene product, parkin, is a ubiquitin-protein ligase. Nat Genet 25, 302-305. 
Slevin, J.T., Gash, D.M., Smith, C.D., Gerhardt, G.A., Kryscio, R., Chebrolu, H., Walton, A., Wagner, R., and Young, A.B. (2007). Unilateral intraputamenal glial cell linederived neurotrophic factor in patients with Parkinson disease: response to 1 year of treatment and 1 year of withdrawal. J Neurosurg 106, 614-620.

Soldner, F., Hockemeyer, D., Beard, C., Gao, Q., Bell, G.W., Cook, E.G., Hargus, G., Blak, A., Cooper, O., Mitalipova, M., et al. (2009). Parkinson's disease patientderived induced pluripotent stem cells free of viral reprogramming factors. Cell 136, 964-977.

Somoza, R., Juri, C., Baes, M., Wyneken, U., and Rubio, F.J. (2010). Intranigral transplantation of epigenetically induced BDNF-secreting human mesenchymal stem cells: implications for cell-based therapies in Parkinson's disease. Biol Blood Marrow Transplant 16, 1530-1540.

Sonntag, K.C., Simantov, R., and Isacson, O. (2005). Stem cells may reshape the prospect of Parkinson's disease therapy. Brain Res Mol Brain Res 134, 34-51.

Stadtfeld, M., Nagaya, M., Utikal, J., Weir, G., and Hochedlinger, K. (2008). Induced pluripotent stem cells generated without viral integration. Science 322, 945-949.

Studer, L., Tabar, V., and McKay, R.D. (1998). Transplantation of expanded mesencephalic precursors leads to recovery in parkinsonian rats. Nat Neurosci 1 , 290-295.

Sullivan, A.M., Opacka-Juffry, J., Hotten, G., Pohl, J., and Blunt, S.B. (1997). Growth/differentiation factor 5 protects nigrostriatal dopaminergic neurones in a rat model of Parkinson's disease. Neurosci Lett 233, 73-76.

Sullivan, A.M., and Toulouse, A. (2011). Neurotrophic factors for the treatment of Parkinson's disease. Cytokine Growth Factor Rev.

Sun, J., Gao, Q., Miller, K., Wang, X., Wang, J., Liu, W., Bao, L., Zhang, J., Zhang, L., Poon, W.S., et al. (2007). Dopaminergic differentiation of grafted GFP transgenic neuroepithelial stem cells in the brain of a rat model of Parkinson's disease. Neurosci Lett 420, 23-28.

Sun, M., Kong, L., Wang, X., Lu, X.G., Gao, Q., and Geller, A.I. (2005). Comparison of the capability of GDNF, BDNF, or both, to protect nigrostriatal neurons in a rat model of Parkinson's disease. Brain Res 1052, 119-129.

Swistowski, A., Peng, J., Liu, Q., Mali, P., Rao, M.S., Cheng, L., and Zeng, X. (2010). Efficient generation of functional dopaminergic neurons from human induced pluripotent stem cells under defined conditions. Stem Cells 28, 1893-1904.

Tain, L.S., Chowdhury, R.B., Tao, R.N., Plun-Favreau, H., Moisoi, N., Martins, L.M., Downward, J., Whitworth, A.J., and Tapon, N. (2009). Drosophila HtrA2 is dispensable for apoptosis but acts downstream of PINK1 independently from Parkin. Cell Death Differ 16, 1118-1125.

Takagi, Y., Takahashi, J., Saiki, H., Morizane, A., Hayashi, T., Kishi, Y., Fukuda, H., Okamoto, Y., Koyanagi, M., Ideguchi, M., et al. (2005). Dopaminergic neurons generated from monkey embryonic stem cells function in a Parkinson primate model. J Clin Invest 115, 102-109.

Takahashi, K., Tanabe, K., Ohnuki, M., Narita, M., Ichisaka, T., Tomoda, K., and Yamanaka, S. (2007). Induction of pluripotent stem cells from adult human fibroblasts by defined factors. Cell 131,861-872. 
Takahashi, K., and Yamanaka, S. (2006). Induction of pluripotent stem cells from mouse embryonic and adult fibroblast cultures by defined factors. Cell 126, 663-676.

Tan, H.L., Fong, W.J., Lee, E.H., Yap, M., and Choo, A. (2009). mAb 84, a cytotoxic antibody that kills undifferentiated human embryonic stem cells via oncosis. Stem Cells 27, 1792-1801.

dTheofilopoulos, S., Goggi, J., Riaz, S.S., Jauniaux, E., Stern, G.M., and Bradford, H.F. (2001). Parallel induction of the formation of dopamine and its metabolites with induction of tyrosine hydroxylase expression in foetal rat and human cerebral cortical cells by brain-derived neurotrophic factor and glial-cell derived neurotrophic factor. Brain Res Dev Brain Res 127, 111-122.

Thomas, K.J., McCoy, M.K., Blackinton, J., Beilina, A., van der Brug, M., Sandebring, A., Miller, D., Maric, D., Cedazo-Minguez, A., and Cookson, M.R. (2011). DJ-1 acts in parallel to the PINK1/parkin pathway to control mitochondrial function and autophagy. Hum Mol Genet 20, 40-50.

Tomac, A., Lindqvist, E., Lin, L.F., Ogren, S.O., Young, D., Hoffer, B.J., and Olson, L. (1995). Protection and repair of the nigrostriatal dopaminergic system by GDNF in vivo. Nature 373, 335-339.

Toriumi, H., Yoshikawa, M., Matsuda, R., Nishimura, F., Yamada, S., Hirabayashi, H., Nakase, H., Nonaka, J., Ouji, Y., Ishizaka, S., et al. (2009). Treatment of Parkinson's disease model mice with allogeneic embryonic stem cells: necessity of immunosuppressive treatment for sustained improvement. Neurol Res 31, 220-227.

Toulouse, A., and Sullivan, A.M. (2008). Progress in Parkinson's disease-where do we stand? Prog Neurobiol 85, 376-392.

Trzaska, K.A., and Rameshwar, P. (2007). Current advances in the treatment of Parkinson's disease with stem cells. Curr Neurovasc Res 4, 99-109.

Unger, C., Felldin, U., Nordenskjold, A., Dilber, M.S., and Hovatta, O. (2008). Derivation of human skin fibroblast lines for feeder cells of human embryonic stem cells. Curr Protoc Stem Cell Biol Chapter 1, Unit 1C 7.

Ungerstedt, U. (1968). 6-Hydroxy-dopamine induced degeneration of central monoamine neurons. Eur J Pharmacol 5, 107-110.

Venkataramana, N.K., Kumar, S.K., Balaraju, S., Radhakrishnan, R.C., Bansal, A., Dixit, A., Rao, D.K., Das, M., Jan, M., Gupta, P.K., et al. (2010). Open-labeled study of unilateral autologous bone-marrow-derived mesenchymal stem cell transplantation in Parkinson's disease. Transl Res 155, 62-70.

Ventimiglia, R., Mather, P.E., Jones, B.E., and Lindsay, R.M. (1995). The neurotrophins BDNF, NT-3 and NT-4/5 promote survival and morphological and biochemical differentiation of striatal neurons in vitro. Eur J Neurosci 7, 213-222.

Vierbuchen, T., Ostermeier, A., Pang, Z.P., Kokubu, Y., Sudhof, T.C., and Wernig, M. (2010). Direct conversion of fibroblasts to functional neurons by defined factors. Nature 463, 1035-1041.

Voutilainen, M.H., Back, S., Porsti, E., Toppinen, L., Lindgren, L., Lindholm, P., Peranen, J., Saarma, M., and Tuominen, R.K. (2009). Mesencephalic astrocytederived neurotrophic factor is neurorestorative in rat model of Parkinson's disease. J Neurosci 29, 9651-9659.

Wakeman, D.R., Dodiya, H.B., and Kordower, J.H. (2011). Cell transplantation and gene therapy in Parkinson's disease. Mt Sinai J Med 78, 126-158. 
Wang, X., Liang, X.B., Li, F.Q., Zhou, H.F., Liu, X.Y., Wang, J.J., and Wang, X.M. (2008). Therapeutic strategies for Parkinson's disease: the ancient meets the future-traditional Chinese herbal medicine, electroacupuncture, gene therapy and stem cells. Neurochem Res 33, 1956-1963.

Wang, Z.H., Ji, Y., Shan, W., Zeng, B., Raksadawan, N., Pastores, G.M., Wisniewski, T., and Kolodny, E.H. (2002). Therapeutic effects of astrocytes expressing both tyrosine hydroxylase and brain-derived neurotrophic factor on a rat model of Parkinson's disease. Neuroscience 113, 629-640.

Warren, L., Manos, P.D., Ahfeldt, T., Loh, Y.H., Li, H., Lau, F., Ebina, W., Mandal, P.K., Smith, Z.D., Meissner, A., et al. (2010). Highly efficient reprogramming to pluripotency and directed differentiation of human cells with synthetic modified mRNA. Cell Stem Cell 7, 618-630.

Weiss, M.L., Medicetty, S., Bledsoe, A.R., Rachakatla, R.S., Choi, M., Merchav, S., Luo, Y., Rao, M.S., Velagaleti, G., and Troyer, D. (2006). Human umbilical cord matrix stem cells: preliminary characterization and effect of transplantation in a rodent model of Parkinson's disease. Stem Cells 24, 781-792.

Wernig, M., Meissner, A., Foreman, R., Brambrink, T., Ku, M., Hochedlinger, K., Bernstein, B.E., and Jaenisch, R. (2007). In vitro reprogramming of fibroblasts into a pluripotent ES-cell-like state. Nature 448, 318-324.

Wernig, M., Zhao, J.P., Pruszak, J., Hedlund, E., Fu, D., Soldner, F., Broccoli, V., Constantine-Paton, M., Isacson, O., and Jaenisch, R. (2008). Neurons derived from reprogrammed fibroblasts functionally integrate into the fetal brain and improve symptoms of rats with Parkinson's disease. Proc Natl Acad Sci U S A 105, 58565861.

Winter, Y., von Campenhausen, S., Reese, J.P., Balzer-Geldsetzer, M., Longo, K., Spiga, G., Boetzel, K., Eggert, K., Oertel, W.H., Dodel, R., et al. (2010). Costs of Parkinson's disease and antiparkinsonian pharmacotherapy: an Italian cohort study. Neurodegener Dis 7, 365-372.

Woltjen, K., Michael, I.P., Mohseni, P., Desai, R., Mileikovsky, M., Hamalainen, R., Cowling, R., Wang, W., Liu, P., Gertsenstein, M., et al. (2009). piggyBac transposition reprograms fibroblasts to induced pluripotent stem cells. Nature 458 , 766-770.

Woodbury, D., Schwarz, E.J., Prockop, D.J., and Black, I.B. (2000). Adult rat and human bone marrow stromal cells differentiate into neurons. J Neurosci Res 61, 364-370.

Xiong, H., Wang, D., Chen, L., Choo, Y.S., Ma, H., Tang, C., Xia, K., Jiang, W., Ronai, Z., Zhuang, X., et al. (2009). Parkin, PINK1, and DJ-1 form a ubiquitin E3 ligase complex promoting unfolded protein degradation. J Clin Invest 119, 650-660.

Xiong, N., Zhang, Z., Huang, J., Chen, C., Jia, M., Xiong, J., Liu, X., Wang, F., Cao, X., Liang, Z., et al. (2011). VEGF-expressing human umbilical cord mesenchymal stem cells, an improved therapy strategy for Parkinson's disease. Gene Ther 18 , 394-402.

Yamanaka, S. (2008). Pluripotency and nuclear reprogramming. Philos Trans R Soc Lond B Biol Sci 363, 2079-2087.

Yamanaka, S., Aoi, T., Yae, K., Nakagawa, M., Ichisaka, T., Okita, K., Takahashi, K., and Chiba, T. (2008). Generation of pluripotent stem cells from adult mouse liver and stomach cells. Science 321, 699-702. 
Yan, Q., Radeke, M.J., Matheson, C.R., Talvenheimo, J., Welcher, A.A., and Feinstein, S.C. (1997). Immunocytochemical localization of TrkB in the central nervous system of the adult rat. J Comp Neurol 378, 135-157.

Yan, Y., Yang, D., Zarnowska, E.D., Du, Z., Werbel, B., Valliere, C., Pearce, R.A., Thomson, J.A., and Zhang, S.C. (2005). Directed differentiation of dopaminergic neuronal subtypes from human embryonic stem cells. Stem Cells 23, 781-790.

Yang, P., Dankowski, A., and Hagg, T. (2007). Protein tyrosine phosphatase inhibition reduces degeneration of dopaminergic substantia nigra neurons and projections in 6-OHDA treated adult rats. European Journal of Neuroscience 25, 1332-1340.

Yasuhara, T., Matsukawa, N., Hara, K., Yu, G., Xu, L., Maki, M., Kim, S.U., and Borlongan, C.V. (2006). Transplantation of human neural stem cells exerts neuroprotection in a rat model of Parkinson's disease. J Neurosci 26, 12497-12511.

Yasuhara, T., Shingo, T., Muraoka, K., Kobayashi, K., Takeuchi, A., Yano, A., Wenji, Y., Kameda, M., Matsui, T., Miyoshi, Y., et al. (2005). Early transplantation of an encapsulated glial cell line-derived neurotrophic factor-producing cell demonstrating strong neuroprotective effects in a rat model of Parkinson disease. J Neurosurg 102, 80-89.

Yoshimoto, Y., Lin, Q., Collier, T.J., Frim, D.M., Breakefield, X.O., and Bohn, M.C. (1995). Astrocytes retrovirally transduced with BDNF elicit behavioral improvement in a rat model of Parkinson's disease. Brain Res 691, 25-36.

Yu, J., Hu, K., Smuga-Otto, K., Tian, S., Stewart, R., Slukvin, II, and Thomson, J.A. (2009). Human induced pluripotent stem cells free of vector and transgene sequences. Science 324, 797-801.

Yu, J., Vodyanik, M.A., Smuga-Otto, K., Antosiewicz-Bourget, J., Frane, J.L., Tian, S., Nie, J., Jonsdottir, G.A., Ruotti, V., Stewart, R., et al. (2007). Induced pluripotent stem cell lines derived from human somatic cells. Science 318, 1917-1920.

Zaiss, A.K., and Muruve, D.A. (2005). Immune responses to adeno-associated virus vectors. Curr Gene Ther 5, 323-331.

Zhang, Y., Schlachetzki, F., Zhang, Y.F., Boado, R.J., and Pardridge, W.M. (2004). Normalization of striatal tyrosine hydroxylase and reversal of motor impairment in experimental parkinsonism with intravenous nonviral gene therapy and a brainspecific promoter. Hum Gene Ther 15, 339-350.

Zhang, Z., Wang, X., and Wang, S. (2008). Isolation and characterization of mesenchymal stem cells derived from bone marrow of patients with Parkinson's disease. In Vitro Cell Dev Biol Anim 44, 169-177.

Zhao, J., and Xu, Q. (2011). Emerging Restorative Treatments for Parkinson's Disease: Manipulation and Inducement of Dopaminergic Neurons from Adult Stem Cells. CNS Neurol Disord Drug Targets.

Zou, Z., Jiang, X., Zhang, W., Zhou, Y., Ke, Y., Zhang, S., and Xu, R. (2010). Efficacy of Tyrosine Hydroxylase gene modified neural stem cells derived from bone marrow on Parkinson's disease--a rat model study. Brain Res 1346, 279-286.

Zurn, A.D., Winkel, L., Menoud, A., Djabali, K., and Aebischer, P. (1996). Combined effects of GDNF, BDNF, and CNTF on motoneuron differentiation in vitro. $\mathbf{J}$ Neurosci Res 44, 133-141. 


\section{CURRICULUM VITAE}

\section{TAREQ AL-MAQTARI}

Date of Birth: August 1, 1979

Email address: almaqtarit@yahoo.com

EDUCATION

Master of Science, Pharmacology/Toxicology $($ GPA= 3.93 $)$

May 2012

- University of Louisville, Louisville, KY, USA

Bachelor of Science, Pharmacy (Distinction)

Feb 2003

- Faculty of Pharmacy, Aleppo University, Aleppo, Syria

\section{RESEARCH AND ACADEMIC EXPERIENCE}

Graduate Teaching Assistant

Nov 2005 - Aug 2010

- Dept. of Pharmacognosy and Phytochemical Chemistry, School of Pharmacy, Sana'a University, Yemen

Pharmacology Instructor

$2006-2009$

Taught several pharmacology courses including: pharmacokinetics, pharmacodynamics, cardiovascular, nervous system, endocrine, gastrointestinal, and chemotherapy pharmacology at:

- Al-Alamia Institute for Medical Training, Sana'a, Yemen

- Al-Rowad College, Sana'a, Yemen

- Al-Wihda Medical Institute, Sana'a, Yemen

- Al-Jazeera Medical Institute, Sana'a, Yemen

- Al-Wataneya University, Sana'a, Yemen

- Ibn Seena Medical Institute, Sana'a, Yemen

- Ibn Hayyan Pharmacy, Sana'a, Yemen 


\section{AWARDS AND HONORS}

Fulbright Scholarship Grantee

2010-2012

- University of Louisville, Louisville, KY, USA

Spotlight Student of the Month

Aug 2011

- University of Louisville, Louisville, KY, USA

Second Best Cumulative GPA at Graduation

- Aleppo University, Aleppo, Syria

Al-Basel Certificate for Academic Excellence

1997-1998

- Aleppo University, Aleppo, Syria

\section{PROFESSIONAL POSITIONS}

Medical Representative

Oct 2002 - Feb 2006

- Lundbeck Pharma, Sana'a, Yemen

\section{WORKSHOPS AND SKILLS}

Research Posters

Jan 2012

- University of Louisville, Louisville, KY, USA

Writing a Literature Review

Nov 2011

- University of Louisville, Louisville, KY, USA

Grantsmanship

Oct 2011

- University of Louisville, Louisville, KY, USA

Effective Research Presentation Skills

Oct 2011

- University of Louisville, Louisville, KY, USA

Fluent in English and Arabic

\section{MEMBERSHIPS}

Yemeni Syndicate for Doctors and Pharmacists

Jan 2003 - Present

- Sana'a, Yemen

Kentucky Academy of Science

Feb 2012 - Present

- Kentucky, USA 